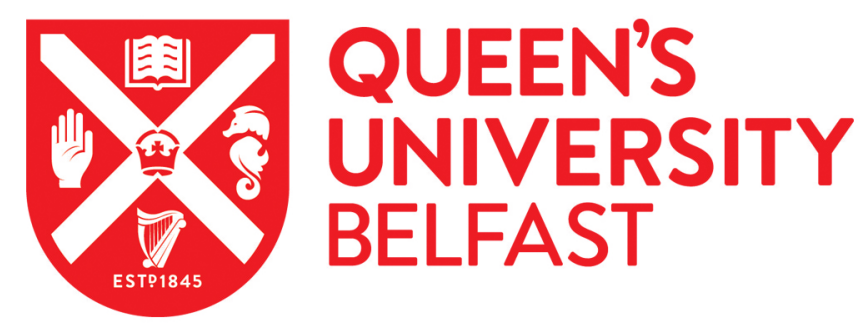

\title{
Smart meter devices and the effect of feedback on residential electricity consumption: Evidence from a natural experiment in Northern Ireland
}

Gans, W., Alberini, A., \& Longo, A. (2013). Smart meter devices and the effect of feedback on residential electricity consumption: Evidence from a natural experiment in Northern Ireland. Energy Economics, 36, 729743. https://doi.org/10.1016/j.eneco.2012.11.022

Published in:

Energy Economics

Document Version:

Peer reviewed version

Queen's University Belfast - Research Portal:

Link to publication record in Queen's University Belfast Research Portal

\author{
Publisher rights \\ Copyright @ 2015 Elsevier B.V. \\ This manuscript version is made available under the CC-BY-NC-ND 4.0 license http://creativecommons.org/licenses/by-nc-nd/4.0/ which \\ permits distribution and reproduction for non-commercial purposes, provided the author and source are cited.
}

\section{General rights}

Copyright for the publications made accessible via the Queen's University Belfast Research Portal is retained by the author(s) and / or other copyright owners and it is a condition of accessing these publications that users recognise and abide by the legal requirements associated with these rights.

\section{Take down policy}

The Research Portal is Queen's institutional repository that provides access to Queen's research output. Every effort has been made to ensure that content in the Research Portal does not infringe any person's rights, or applicable UK laws. If you discover content in the Research Portal that you believe breaches copyright or violates any law, please contact openaccess@qub.ac.uk. 


\section{Accepted Manuscript}

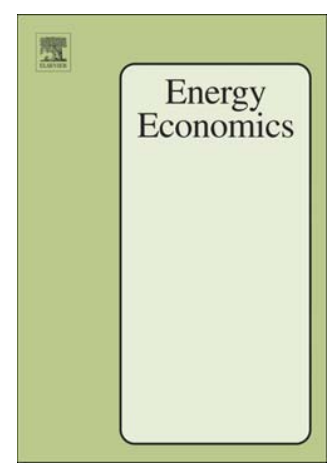

Smart Meter Devices and The Effect of Feedback on Residential Electricity Consumption: Evidence from a Natural Experiment in Northern Ireland

Will Gans, Anna Alberini, Alberto Longo

PII:

S0140-9883(12)00320-9

DOI:

doi: 10.1016/j.eneco.2012.11.022

Reference: ENEECO 2449

To appear in: $\quad$ Energy Economics

Received date: 18 January 2012

Revised date: 27 August 2012

Accepted date: 21 November 2012

Please cite this article as: Gans, Will, Alberini, Anna, Longo, Alberto, Smart Meter Devices and The Effect of Feedback on Residential Electricity Consumption: Evidence from a Natural Experiment in Northern Ireland, Energy Economics (2012), doi: 10.1016/j.eneco.2012.11.022

This is a PDF file of an unedited manuscript that has been accepted for publication. As a service to our customers we are providing this early version of the manuscript. The manuscript will undergo copyediting, typesetting, and review of the resulting proof before it is published in its final form. Please note that during the production process errors may be discovered which could affect the content, and all legal disclaimers that apply to the journal pertain. 


\title{
Smart Meter Devices and The Effect of Feedback on Residential Electricity Consumption: Evidence from a Natural Experiment in Northern Ireland
}

\author{
by
}

\author{
Will Gans, Anna Alberini and Alberto Longo
}

Last revision: 27 August 2012

Last revision by: Anna Alberini

August 2012

Address for correspondence:

Anna Alberini, AREC, 2200 Symons Hall, University of Maryland College Park, MD 20742 aalberini@arec.umd.edu

Authors' affiliations: Gans is a consultant with National Economic Research Associates (NERA) in Washington, DC (will.gans@ @era.com); Alberini is an associate professor at the AREC, University of Maryland, College Park (aalberini@arec.umd.edu) and Longo is a lecturer at the School of Biological Sciences, Queen’s University, Belfast (a.longo@qub.ac.uk).

We wish to thank Iain Bryson of the Northern Ireland Statistics and Research Agency, Gerry Forde and Maureen Delaney of Northern Ireland Energy, Joy McFarland of Phoenix Gas, George Hutchinson of Queen's University, Belfast, Severin Borenstein, and participants of Queen's University Energy Economics Workshop, held in Belfast in January 2011 for their help with this project. 


\title{
Smart Meter Devices and The Effect of Feedback on Residential Electricity Consumption: Evidence from a Natural Experiment in Northern Ireland
}

\begin{abstract}
:
Using a unique set of data and exploiting a large-scale natural experiment, we estimate the effect of real-time usage information on residential electricity consumption in Northern Ireland.

Starting in April 2002, the utility replaced prepayment meters with advanced meters that allow the consumer to track usage in real-time. We rely on this event, account for the endogeneity of price and payment plan with consumption through a plan selection correction term, and find that the provision of information is associated with a decline in electricity consumption of 11-17\%. We find that the reduction is robust to different specifications, selection-bias correction methods and subsamples of the original data. The advanced metering program delivers reasonably costeffective reductions in carbon dioxide emissions, even under the most conservative usage reduction scenarios.
\end{abstract}

JEL Classification: Q40, Q41, D8

Keywords: Residential Energy, Electricity Demand, Feedback, Smart Meter, Information 


\section{Smart Meter Devices and The Effect of Feedback on Residential Electricity Consumption: Evidence from a Natural Experiment in Northern Ireland}

by

\section{Will Gans, Anna Alberini and Alberto Longo}

\section{Introduction and Motivation}

Residential buildings account for a large share of the world's energy consumption, and offer a natural target for policies that seek to reduce $\mathrm{CO}_{2}$ emissions from (fossil-fuel) power generation, dependence on imported fuels, and vulnerability to supply shocks. For these reasons, there is tremendous policy interest in programs to reduce energy consumption and increase energy efficiency in the residential sector.

It is difficult for consumers to keep track of current electricity usage and/or predict future electricity demand. ${ }^{1}$ Many observers argue that providing better information and feedback on consumption helps improve energy conservation and energy efficiency in the residential sectorby itself or when combined with other traditional policy tools such as economic incentives, pricing and regulation. Earlier evaluations of information-based approaches, however, relied on short-lived pilot projects or small groups of households, which resulted in small sets of data (Fischer, 2008; Ehrhardt-Martinez et al., 2010), and have been complicated by self-selection issues due to the voluntary nature of certain initiatives, such as utility-provided audits (Hartman, 1988; Waldman and Ozog, 1996).

Recent technological advances, such as "smart" and advanced meters and the associated infrastructure (advanced metering infrastructure, or AMI), can give consumers feedback on

\footnotetext{
${ }^{1}$ Other goods that share these features include, for example, cell phone minutes and internet access time (Grubb, 2009). Della Vigna and Malmendier (2006) and Lambrecht and Skiera (2006) study preferences for three-part tariffs and flat rate even when the consumer would save money by choosing alternate pricing schemes, which they attribute to underestimating the variance of future demand, risk and loss aversion, and disutility associated with the price per se.
} 
consumption by combining frequent automated usage readings with accessible displays. AMI has received much recent attention and, at least in the US, generous federal funding. Despite the scale of support from the government and the utility industry, there has been little evaluation of these programs.

In this paper, we use an advanced metering implementation in Northern Ireland to provide the first large-scale evidence of the effect of usage feedback on residential consumption. Specifically, we estimate household response to the provision of immediate feedback about electricity consumption.

Northern Ireland is a unique setting for studying residential energy consumption for three reasons. First, the retail residential rates are among the highest in the United Kingdom and Europe, but, until recently, consumers lacked an alternative provider for electricity. This suggests that they may be willing to make behavioral changes to save on their energy bills when given an opportunity to do so. ${ }^{2}$

Second, there are a host of payment plan options for electricity in the Northern Ireland market. These include credit accounts, direct debit accounts, and prepayment accounts. The variation in attributes across plans allows us to identify the effect of price and changes in other important plan features.

Third, one of these plans (prepayment) recently experienced an exogenous change in technology (the keypad) which provides immediate feedback about usage. Moreover, because this plan requires prepayment, it suggests that households on it will be monitoring their usage. The switch away from the previous meter that served prepayment customers, which did not have these capabilities, occurred in April 2002. We interpret this as the treatment in a natural

\footnotetext{
2 These incentives should be particularly strong for so-called "fuel poor" households. Government estimates suggest that about one-third of the households in Northern Ireland are "fuel poor," with fuel poverty being defined when $10 \%$ or more of the household income is spent on all household fuel use (DSDNI, 2006).
} 
experiment and use it to identify how electricity consumption was affected among the "treatment" customers. Our "controls" are customers in other plans (which do not use AMI meters and do not provide real-time information about usage to the consumer). This is a large scale natural experiment, since $14 \%$ (over 75,000 ) of the NIE customer base was on a prepayment plan at the time of the switch to the keypad metering technology.

Economic theory does not predict unambiguously the effect of information on electricity usage on electricity consumption. Gans et al. (2011) develop a simple theoretical model where the fraction of energy wasted is controlled with monitoring and information, which can be either substitutes or complements. In this framework, there are countervailing incentives to substitute electricity savings for savings on monitoring. Whether or not feedback (i.e., the keypad) about usage enables consumers to reduce their electricity demand (through conservation or energyefficiency investments) is, therefore, an empirical issue.

We examine this matter using data from 18 waves of Northern Ireland's Continuous Household Survey (from 1990 to 2009), which we merge with price and plan information from the electricity utility, and weather data. Our dataset is a multi-year cross-section and is comprised of over 45,000 usable observations. Despite the single-provider electricity market, prices varied over time and across payment plans during our study period. Since electricity price depends on the plan, but plan choice may depend on unobserved household characteristics that influence both consumption and plan selection, we implement the Dubin-McFadden (1984) correction in our demand equations. We also account for unobserved heterogeneity using geographic fixed effects. We find that controlling for housing type, heating, household characteristics and selection into the plan, the keypad results in 11-20\% less electricity use. 
The keypad may provide a cost-effective alternative to large scale rebate or efficiency incentive programs in meeting emission reduction and demand response goals. In terms of $\mathrm{CO}_{2}$ emissions, we find that the keypad delivers emissions reductions at a cost per tonne of $\mathrm{CO}_{2} \mathrm{e}$ of $£ 25$ or less, where $£ 25$ is the price of carbon used by the UK government in its policy analyses (DECC, 2009). Other benefits of the keypad or similar usage feedback systems, which we do not try to assess in this paper, include reduced metering, billing, outage investigation and fraudrelated costs for the utility, reductions in conventional air pollution associated with power generation, and improved energy security.

The remainder of the paper is organized as follows. Section 2 reviews the previous literature. Section 3 describes the utilities of Northern Ireland, prices and plans for the residential sector. Section 4 presents the model and the empirical approach. Section 5 describes the data. Section 6 presents the results. We offer concluding remarks in Section 7.

\section{Previous Literature}

Imperfect information and uncertainty about the price of electricity have received much attention in the energy economics literature. Shin (1985) discusses consumers' use of the average price of electricity (as opposed to the marginal price) when it is difficult to track due to seasonal price changes, block tariffs, and fuel surcharges. Hassett and Metcalf (1993) and Metcalf and Rosenthal (1995) study the effects of uncertainty about future energy prices on the pattern of energy efficiency investments. Ito (2010) summarizes alternative models of consumer behavior in the presence of block pricing, showing that people will invest effort in finding out the price of energy only to the point in which the gains from re-optimizing consumption decisions exceed the cost of the effort spent monitoring and investigating prices. 
In contrast, the literature on consumer response to information about energy usage (as opposed to price) is relatively scant. Traditionally, utilities have provided information to a customer about his or her energy consumption level (and on how to reduce it) by offering free or low-cost audits. ${ }^{3}$ Individualized audits, however, are typically utilized by only a small fraction of the customer base. Because they are voluntary, it is likely that people who reduce energy use after an audit would have done so anyway. Hartman (1988) finds that audits do decrease energy usage, but that failure to account for self-selection grossly overstates the impact of the audit program. To illustrate, during 1977-1981 (his study period) the average conservation truly attributable to the program is $951 \mathrm{kWh} / \mathrm{yr}$ - only $39 \%$ of the savings calculated based on a naïve comparison between participants and non-participants.

Waldman and Ozog (1996) use a sample of participants and non-participants in a choicebased sampling framework, and assume that, absent any type of incentive, there is a "natural" level of conservation, which they identify using the consumers who are not aware of the existence of utility incentives (and consequently receive zero incentive). They estimate that the program truly accounts for only $71 \%$ of the total conservation, the remaining $29 \%$ being "natural" conservation (i.e. that would have happened regardless).

While audits are typically one-off events, recently attention has been focused on ways to provide continuous, or at least frequent, feedback to consumers about their energy usage. Darby (2006) surveys earlier studies involving the provision of information, both direct ("immediate, from the meter or an associated display monitor"), and indirect ("feedback that has been

\footnotetext{
${ }^{3}$ These are often included in the utilities' Demand Side Management (DSM) programs, along with other initiatives for encouraging conservation and peak load management. See Loughran and Kulick (2004) and Auffhammer et al. (2008) who compute the cost per kWh saved by DSM programs in the US in the 1990s. Dulleck and Kaufmann (2004) use monthly time series data for household electricity usage in Ireland from 1976 to 1993 and relate them to Demand Side Management policies that provided information and offered minor incentives to customers. Their analysis is constrained by the fact that they observe only aggregate data, so they estimate a seasonally-adjusted timeseries model of energy usage. They find that the introduction of information programs reduces long-term electricity usage by $7 \%$.
} 
processed in some way before reaching the energy user, normally via billing”). Reductions in consumption are in the 5-15\% and 0-10\% range, respectively. These are in line with the estimates documented in the review by Ehrhardt-Martinez et. al (2010). ${ }^{4}$

Gleerup et al. (2010) study SMS cell phone and e-mail messaging to alert consumers when usage levels are exceptionally high, and find that these approaches reduced consumption by about $3 \%$. In this paper, however, we are concerned with the feedback about electricity usage provided by devices placed in the consumer's home. Matsukawa (2005) estimates the effect of feedback information on residential energy usage in Japan. He finds that those residential customers who were given access to an informational display explaining how to use appliances more efficiently reduced energy usage by $1 \%$, even though the display was not connected with any one appliance and no monetary incentives were offered to encourage conservation.

A more technologically sophisticated approach to provide usage information is to deploy advanced metering devices. These include "smart" meters and advanced meters. Smart meters are two-way wireless communication devices that i) measure, store and transmit usage data to the utility at regular intervals, allowing it to monitor usage and bill the customer for it remotely without having to physically read the meter, and ii) can be used to convey real-time tariff changes, supply-wide conditions and peak-load information to the consumer (Darby, 2010). ${ }^{5}$

\footnotetext{
${ }^{4}$ One way to enhance or manipulate the feedback provided by regular utility bills is to augment it with "social norms" contents. In a randomized field experiment involving 80,000 households in Minnesota, information about the energy usage of neighbors and visual cues about doing "better" or "worse" in electricity usage relative to similar neighboring homes has been found to reduce energy consumption by $1.9 \%$ relative to the baseline (Allcott, 2008). The effect decayed over time, perhaps because of the diminishing scope for learning from a neighbor's bill over time. Effects of similar magnitude ( $2 \%$ and $1.2 \%$, respectively) were observed in similar large-scale randomized trial experiments in Sacramento, California, and Portland, Oregon (Ayres et al., 2009). These declines in usage were sustained over time, and were generally proportionally larger among households with large pre-treatment consumption. In one of the two study locales (Sacramento) electricity consumption actually increased among households with low pre-treatment usage.

${ }^{5}$ Smart meters are also used to implement dynamic pricing plans. Briefly, dynamic pricing refers to any electricity tariff that changes over time, but where the levels and/or timing when these prices are in effect are unknown (Faruqui and George, 2002). Lijesen (2007) summarizes evidence about real-time pricing (a type of dynamic
} 
Advanced meters (usually referred to as Automated Meter Readers, or AMRs) are simpler, oneway communication devices that perform only function i).

Either type of meter can be used to provide instantaneous usage level updates to the customer, for example by using an in-home display. ${ }^{6}$ Presumably, this usage information assists consumers in adjusting consumption through conservation or by investing in energy-efficiency equipment. Advanced metering is an important component of the so-called "smart grid" and in 2009 the US federal government awarded over $\$ 4$ billion to projects aimed at modernizing the grid under President Obama's "Stimulus Act" (see www.smartgrid.gov).

In Europe, in 2009 the European Commission's Directive 2009/72/EC (European Commission, 2010) requires Member States to "ensure the implementation of intelligent metering systems that help consumers to participate actively in the electricity and gas supply markets." The Directive further requires that "Where an economic assessment of the long-term costs and benefits has been made, at least $80 \%$ of those consumers who have been assessed positively, have to be equipped with intelligent metering systems for electricity by 2020 ," and that consumers be informed of "actual electricity consumption and costs frequently enough to enable them to regulate their own consumption." Implicit in this statement is the assumption that providing feedback about usage can and does result in adjustments and changes to usage itself, which is the research question at the heart of this paper.

To our knowledge, however, only few projects funded by governments or the utilities have allowed consumers to access information about usage in real time. The majority of these projects have been small in scope and duration (Fischer, 2008), or have omitted important variables, thwarting efforts to evaluate the impacts of information on electricity consumption.

pricing) and Wolak (2011) provides a recent assessment of peak-load based pricing using data from one such program in the Washington, DC, area in 2008-09.

${ }^{6}$ Darby (2010) notes that in-home display devices are frequently, but incorrectly, referred to as "smart meters." 
ACEEE (2010), for example, classifies a study as a "large" study when there are as few as 100 subjects.

Fischer (2008) selects 26 projects from various countries over 1987-2006 where feedback about electricity consumption was provided to residential customers, and concludes that overall feedback does reduce usage by $1-20 \%$ percent, with "usual" savings in the $5-12 \%$ range. She identifies aspects of the feedback provision that were most successful at reducing usage, such as breakdown by appliance, computerized and very frequent feedback — which are made possible by advanced metering — and sufficiently long project duration. These conclusions should be interpreted with caution, however, because only 6 out of the 26 projects involved breakdown by appliance, the projects were mostly short-lived, and they involved relatively small groups of consumers.

Faruqui et al. (2010) review 12 projects conducted between 1989 and 2010 in the US and Canada, with participation ranging between 60 and 3500 residential customers. The availability of usage information reduces consumption by $3-14 \%$ (average $7 \%$ ), with an even more pronounced effect (13-15\%) when accompanied by pre-payment electricity service plans.

Ideally, when evaluating the effect of real-time usage information, one would like to observe a relatively large group where the information feedback is varied across individuals, and compare results with those from a group with no information treatment, before and after the introduction of feedback. What we describe in this paper is one such natural experiment. We take advantage of the introduction of an advanced metering device to a group of utility customers in Northern Ireland in 2002. This device replaced a preexisting meter that did not display information. The meters and meter replacement affected only customers on a prepayment plan; 
those on other plans were not affected, suggesting that the latter serve as a "control group."7 We have a large sample with tens of thousands of households, extensive information on dwelling and household characteristics, and we take advantage of the variety of utility plans available in Northern Ireland to study on this important question.

\section{Background on Utilities and Pricing Schemes in Northern Ireland}

As we explain in detail below, we use data from a large multi-year cross-section survey of households in Northern Ireland. Our study period is 1990-2009, and during this time Northern Ireland Electricity (NIE) was the electric monopoly for the residential sector in all of Northern Ireland. As of September 2010, NIE had approximately 750,000 residential customers with an average annual consumption of $4100 \mathrm{kWh}^{8,9}$

We use NIE's historical tariff information, from 1990 to the present, to construct our electricity price data and convert bills to $\mathrm{kWh}$ used. NIE has offered a variety of pricing and payment schemes throughout our study period (see tables 1 and 2). ${ }^{10}$ NIE's prices tend to be somewhat higher than electricity tariffs in the rest of the UK. For example, in 2009-the last year of our study period - at $3300 \mathrm{kWh}$ a year, the average price per kWh (inclusive of Value Added Tax [VAT]) in Northern Ireland was $£ 0.1558$ for "credit" customers (those who pay their bill upon receiving it in the mail), £0.1499 for direct debit customers and $£ 0.1518$ for prepayment customers. In the same year, the UK averages were $£ 0.1346, £ 0.1240$ and $£ 0.1386$,

\footnotetext{
${ }^{7}$ In a paper examining payment behavior of prepayment customers, Brutscher (2011) uses a propensity score matching technique to estimate a consumption reduction for NIE keypad customers. However, his approach is limited by (i) the omission of price from his demand equation, and (ii) the short time period and small sample from which he draws his data. The utility's own assessment of the effect of the keypad (Boyd, 2008) is limited to a sample of 324 customers and is silent about recruitment into the study, study period, and statistical technique used. ${ }^{8}$ Communication by Gerry Forde of NIE, 7 December 2010.

${ }^{9}$ The Northern Ireland residential market was opened to competition in June 2010, and NIE estimates that it loses about 3000 customers a month because of this. Competition existed before 2010 in the commercial and industrial markets.

${ }^{10}$ Detail on NI Electric's latest prices are available at http://www.nieenergy.co.uk/latestprices.php.
} 
respectively, and even London's tariffs were lower than those in Northern Ireland (UK Department of Energy and Climate, 2012).

The default payment frequency is quarterly, but there are discounts available for customers who choose to pay by direct deposit, or who choose a pay-as-you go (prepayment) plan. As shown in table 1, from 1990 until 1997 NIE charged its customers a fixed fee and a constant tariff per kWh. Starting in April 1997, a two-part tariff was instituted, with a fixed fee and decreasing block pricing. The prices were 9.16 pence per $\mathrm{kWh}$ in the first block (up to 250 kWh per quarter) and 8.16 pence per kWh thereafter. In April 1999, NIE eliminated both the block tariff and the fixed fee, and introduced a constant rate per $\mathrm{kWh}$.

Nominal prices per kWh increased regularly over our study period, and a steep hike occurred in July 2008, when the rate per kWh increased by almost one-third. Prices subsequently went down somewhat, but never returned to the pre-July 2008 levels. In addition to this variation in the structure of electricity pricing and in the rate per $\mathrm{kWh}$ over time, discounts were and are given to customers on various plans, as summarized in table 2. For example, starting in April 1997, EasySaver and Budget customers received a $1.5 \%$ discount, not to exceed $£ 10$ per year. ${ }^{11}$ Since April 2002, those customers on NIE's direct debit monthly and direct debit quarterly plans ("managed" plans with even monthly or quarterly payments) have received a $4 \%$ and $2.5 \%$ discount, respectively, up to a specified maximum annual discount (which was initially $£ 5$ and is now $£ 40$ for the monthly and $£ 25$ for the quarterly schemes, respectively).

Throughout our study period, NIE offered a prepayment program to customers.

Originally, a coin-operated device was used that had to be "charged" with coin deposits in order

\footnotetext{
${ }^{11}$ An EasySaver card is a scheme that allows customers to flexibly pay their bill in installments. If, at the time of issuing a new bill, there is less than $10 \%$ balance on their card (or less than $£ 10$ ), they receive a discount. Under a budget account, the customer gets a discount by agreeing to make fixed regular payments. If they miss payments, they lose the discount. While the discounts are identical for these plans, the budget is a "managed" plan with regular and fixed payment amounts, whereas an EasySaver plan allows payment amounts and frequencies to vary.
} 
to dispense electricity. In 1993, NIE replaced coin-operated devices for new customers with electronic systems, introducing the powercard, which used a plastic debit-type card. Customers added money to the card and then inserted it into the meter for electricity to start flowing into the home. Owen and Ward (2007) report that the powercard system required visiting the customer's home to change tariffs, was vulnerable to theft and fraud, and required tracking down and reconciling usage and billing. Customers frequently experienced card malfunctioning (i.e., loss of magnetization) and breakage.

In 2002, all prepayment customers were switched to a new program called Home Energy Direct (commonly dubbed "keypad"). The keypad system eliminated the equipment charge for prepayment, and the entire stock of older prepayment devices was replaced with the new technology. Concurrent to the switch to the keypad, customers on this plan started receiving a $2.5 \%$ discount (with no maximum limit) and the fixed fee was eliminated. ${ }^{12}$

The keypad meters combine prepayment with an interactive display that allows consumers to easily monitor their electric usage and cost. The keypad customer purchases credit from a store kiosk, over the telephone or on-line, and receives a "vend code," which he enters into the keypad to activate it. Plastic cards are no longer used with the keypad system (Owen and Ward, 2007). Using the keypad display, customers can check at any time i) how much credit they still have on the card, ii) an estimate of how many more days the credit will be sufficient for, based on the previous week's consumption, iii) usage and cost summaries of the previous day, week or month, and iv) real-time electricity usage in $\mathrm{kWh}$, along with the associated cost in pounds.

The keypad does not display an appliance-by-appliance breakdown of usage, although it should be possible for a consumer to figure it out by sequentially turning on and off individual

\footnotetext{
${ }^{12}$ Variation in prices was introduced for customers on other plans at the same time.
} 
appliances one at a time. A chime warns the customer when the credit is about to be completely exhausted, and a small credit $(£ 1)$ is automatically granted when the credit on the card runs out. In sum, the keypad is an advanced meter device (with one-way communication) which automatically monitors electricity usage at very frequent intervals (several times per hour), and offers the additional functionality of a pay portal and a usage display. As of November 2010, households on the keypad accounted for $34 \%$ of the NIE residential customer base, direct debit monthly plans for $26 \%$, direct debit quarterly for $4.7 \%$, budget accounts for $0.2 \%$ and EasySavers for 6.3\%. Customers on no particular plan (e.g., such as those who receive quarterly bills and pay them in cash or by check) accounted for $27.7 \%$ of the NIE residential customer base. $^{13,14}$

\section{Model and Empirical Approach}

\section{A. Theoretical Motivation}

We are interested in modeling the response to information that a typical prepayment customer will experience after the introduction of the keypad device. A customer with perfect information would always know their electricity consumption, associated bill, and remaining balance on the prepayment card. Displaying usage information would therefore have no effect on such a consumer.

What fully informed and rational consumers would do is one thing; what happens to reallife consumers is another. We argue that inattention is unavoidable: For many consumers, the

\footnotetext{
${ }^{13}$ Personal communication from Gerry Forde, NIE, 15 December 2010.

${ }^{14}$ Prepayment is thus much more widespread in Northern Ireland than in the rest of the UK: in the same period, only $15 \%$ of the UK residential customers subscribed to prepayment plans (UK Department of Energy and Climate Change, 2012b). Faruqui et al. (2010) report that worldwide over 5 million customers use power on a pre-payment basis, with the bulk of pre-payment users in the UK, New Zealand and South Africa. The only two North America instances of pre-pay pricing plans reported in Faruqui et al. are offered by Woodstock Hydro in Ontario, Canada and the Salt River Project utility in Arizona.
} 
gains from monitoring usage are insufficient to justify much monitoring effort (Ito, 2010). As a result, little monitoring of usage occurs, and consumers imperfectly observe their electricity usage. We attribute any "surprise" in the amount of usage to inattention on the part of the consumer. Observed changes in consumption after an informational device is provided suggest that the device did provide "surprise" to inattentive consumers.

Easier-to-read, real-time information about usage may increase the productivity of monitoring, or may serve as a substitute for it. Gans et al. (2011) propose a simple model where the consumer derives utility from energy services, and where some electricity is wasted (perhaps because the consumer fails to unplug appliances when not in use, or uses them improperly, etc.). This model, however, does not provide unambiguous predictions as to whether an exogenous change in information increases or decreases monitoring and electricity consumption. The competing effects of productivity gains in monitoring from information and an income effect that enables more consumption or monitoring make the direction of the effect indeterminate. The effect of enhanced information on electricity use is, therefore, an empirical question.

\section{B. The Experiment and the Treatment}

Suppose individuals in a population were assigned at random to a treatment and control group for the purpose of determining the effect of the treatment on an outcome variable. Under these assumptions, the observed difference in mean outcome is a consistent estimate of the average treatment effect on the treated:

$$
E\left(y_{i} \mid c_{i}=1\right)-E\left(y_{i} \mid c_{i}=0\right)=E\left(y_{1 i}-y_{0 i} \mid c_{i}=1\right),
$$


where $c$ is a dummy that takes on a value of one when the treatment is in place, and zero otherwise, $y_{i}$ is individual i's observed outcome, and $\mathrm{y}_{1}$ and $\mathrm{y}_{0}$ are the potential outcomes with and without the treatment (see Angrist and Pischke, 2009).

If the assignment to the treatment and control groups is not random, the right-hand side of (1) contains an additional term, namely the selection bias, which is equal to $E\left(y_{0 i} \mid c_{i}=1\right)-E\left(y_{0 i} \mid c_{i}=0\right)$. Conventional approaches, such as the difference-in-difference estimator or OLS regressions, fail to control for selection bias, but it is possible to get around this problem by using propensity score matching, Heckman two-step methods, or other procedures to construct a term that soaks up the selection bias (Vella, 1998).

As mentioned, in this paper, we exploit the fact that in April 2002, NIE introduced a new metering device - the keypad - that allows customers to track consumption in real time, and a new pricing structure for its prepayment plan. New prepayment customers were placed directly on the keypad plan, and preexisting customers were moved en masse to the keypad, thus replacing the existing meters with the more advanced ones and applying the new pricing structure. At the same time, the pricing of other plans was changed.

We interpret the introduction of the new metering device as the treatment of interest, customers on prepayment as the treatment group, and electricity consumption as the outcome of interest. Our control group is comprised of customers on all other plans. Since the price depends on the plan, customers select into their plan, and plan choice may be correlated with energy use patterns, there is potential for selection bias. We control for selection bias by using the DubinMcFadden selection correction approach, which is well suited to the situation in which people select into one of a finite number of possible states. 


\section{The Sample}

We pooled the data from 18 consecutive waves of the Continuous Household Survey of Northern Ireland, starting with the 1990-91 wave and ending with the 2008-09 wave. The Continuous Household Survey (CHS) is an annual survey conducted by the Northern Ireland Research and Statistics Agency (NISRA). It is representative of the (civilian) population of Northern Ireland. The CHS elicits information about the dwelling (including type and size of the home, tenure, heating, and various living expenses, such as energy), health, education, employment and welfare payments.

The surveys are conducted year-round, with approximately 300 households surveyed in each month, and cover different housing types, income levels, and geographic regions. Different households are interviewed in each wave of the survey, and so by pooling several waves we obtain a multi-year cross-section dataset, rather than a panel. ${ }^{15}$ A breakdown of the data by year is presented in table 3 .

Characteristics of the dwelling (including the type of structure, size and age, and ownership) come from the "Tenure" section of the questionnaire, whereas information about heating and energy use comes from the "Heating" module of the questionnaire. The respondent is asked whether the home has central heating, and what fuels are used for heating the home, distinguishing between summer and winter heating. He is also asked if each of these fuels is used for heating water and for cooking. The questionnaire also elicits the expenses associated with each fuel. Next, the interviewer is instructed to ask the respondent to produce the most recent

\footnotetext{
${ }^{15}$ It would be interesting to use panel data provided by the utility and containing electricity billing records for customers on various supply plans over a sufficiently long period of time, but we do not have such data. One limitation of utility-provided billing records is that usually such datasets do not contain information about structural characteristics of the dwelling, heating and air conditioning and household characteristics that might explain plan selection and usage (Ito, 2010; Borenstein, 2009). Other government-conducted longitudinal surveys, like the British Household Panel Survey (used, for example, in Meier and Redhanz, 2010), document energy household energy expenditure but stopped collecting information about the household's pricing plan well before the keypad was introduced.
} 
electricity bill, and to record the amount billed for the last quarter. ${ }^{16}$ Further questions inquire about how the respondent's household pays for electricity (plan and mode of payment), how much he paid most recently, and what period that payment covered.

\section{Electricity Demand}

We begin with the demand equation:

$$
\ln E_{i j t}=\beta_{0 j}+\beta_{1} \ln p_{i t}+\beta_{2} \ln I N C_{i j t}+\mathbf{x}_{i j t} \gamma+\eta_{i j t}
$$

where $\mathrm{E}$ is electricity usage (in $\mathrm{kWh}$ ), $\mathrm{p}$ is the price per $\mathrm{kWh}, \mathrm{INC}$ is household income, and $\mathbf{x}$ is a vector of variables thought to influence electricity consumption (weather, characteristics of the home and of the household, type of heating and appliances used, dummies for the month or year when the household was interviewed). Subscripts i, j and t denote the household, area where the household resides, and wave of the CHS surveys, respectively. Clearly, $\beta_{1}$ and $\beta_{2}$ are the price and income elasticities, respectively, of electricity demand.

As previously explained, the price of electricity varies across plans, and households select their electricity plans. Unobservable household characteristics may influence both a household's choice of plan, and hence the price per kWh it faces, as well as this household's electricity consumption. This makes price and consumption endogenous. To remedy this problem, we implement a two-step estimation methodology based on Dubin and McFadden (1984).

Specifically, we assume that households choose a plan to maximize utility. We posit that a household's indirect utility is a function of characteristics of the households and the home:

$$
V_{i k}=\mathbf{Z}_{\mathbf{i}} \boldsymbol{\theta}_{\mathbf{k}}+\varepsilon_{i k}
$$

\footnotetext{
${ }^{16}$ Any arrears are subtracted, so that the CHS records only the amount billed for the last billing period.
} 
where $\mathrm{i}$ denotes the household, $\mathrm{k}$ denotes the plan, $\mathbf{Z}$ is a vector of characteristics of the household and/or the home, and $\varepsilon$ is an i.i.d. extreme value error term with scale 1 . The household chooses the alternative with the greatest utility, and so the probability of choosing plan $\mathrm{k}$ is:

$$
\operatorname{Pr}(k)=\exp \left(\mathbf{Z}_{i} \boldsymbol{\theta}_{k}\right) /\left[\sum_{j=1}^{J} \exp \left(\mathbf{Z}_{i} \boldsymbol{\theta}_{j}\right)\right]
$$

with $\boldsymbol{\theta}_{1}$ normalized to zero for identification.

We allow for possible correlation between $\eta$ and $\varepsilon$, which makes electricity usage and the choice of plan endogenous. To obtain consistent estimates of the coefficients in equation (2), we must condition on the choice of plan. Dubin and McFadden assume that

$$
E(\varepsilon \mid \eta)=\frac{\sigma \sqrt{6}}{\pi} \sum_{m \neq k}^{K} r_{m}\left(\varepsilon_{m}-E\left(\varepsilon_{m}\right)\right)
$$

where $r_{m}$ is the correlation coefficient between $\eta$ and $\varepsilon_{m}$. Dubin and McFadden show that the coefficients in equation (2) can be estimated consistently by running OLS on

$$
\ln E_{i j t}=\beta_{0 j}+\beta_{1} \ln p_{i t}+\beta_{2} \ln I N C_{i t}+\mathbf{x}_{i t} \gamma+\sum_{m \neq k} \alpha_{m}\left(\frac{\hat{P}_{i m t} \cdot \ln \hat{P}_{i m t}}{1-\hat{P}_{i m t}}\right)+\alpha_{k} \cdot \ln \hat{P}_{i k}+e_{i j t}
$$

where $\mathrm{k}$ is the plan selected by household i, m denotes a plan, the $\hat{P}_{\mathrm{s}}$ denote the predicted probabilities of selecting the various plans from the first-step multinomial logit of the observed plan choices, and the as are the correlation coefficients from (5) rescaled by the standard deviation.

Bourguignon et al. (2007) compare the performance of the Dubin-McFadden correction term in (6) with a simplified version that imposes the constraint that the $\alpha$ coefficients sum to zero, and with the selection correction procedures developed by Lee (1983) and Dahl (2002). 
They conclude that (6) is the most robust. We report regression results based on (6), and repeat the same regressions with alternate selection correction procedures for good measure.

Since our sample is comprised of multi-year cross-sections drawn from the population of Northern Ireland, it is impossible to include household-specific effects, and we lack information to develop pseudo-panels based on detailed geography and housing type information (Deaton, 1985; Bernard et al., 2010). We control for unobserved heterogeneity by including ward-specific intercepts (the $\beta_{0 j}$ in equation (2)), under the assumption that the households and/or the dwellings in a ward are similar. ${ }^{17}$

\section{E. The Effect of Usage Information on Usage}

The question at the heart of this paper is whether providing feedback about consumption of electricity makes consumers change their usage levels. In April 2002 NIE replaced the powercard plan with the keypad plan, which substituted the old meter with a more advanced device that displayed real-time information. What is the (average) effect of such a change?

To answer this question, we amend equation (6) to include dummies for the type of plan the household is on. Formally,

$$
\ln E_{i j t}=\beta_{0 j}+\beta_{1} \ln p_{i t}+\beta_{2} \ln I N C_{i t}+\mathbf{x}_{i t} \boldsymbol{\gamma}+\mathbf{D}_{i j t} \boldsymbol{\delta}+\sum_{m \neq k} \alpha_{m}\left(\frac{\hat{P}_{i m t} \cdot \ln \hat{P}_{i m t}}{1-\hat{P}_{i m t}}\right)+\alpha_{k} \cdot \ln \hat{P}_{i k}+e_{i j t}
$$

where $\mathbf{D}$ is a vector of dummies for the electricity scheme the household is on, and vector $\boldsymbol{\delta}$ captures the effect that the type of plan has on electricity, above and beyond that of the price associated with that plan. We estimate equation (7) in two steps, using the selection correction

\footnotetext{
${ }^{17}$ Northern Ireland is divided into twenty-six local governmental units called districts. Each district is a collection of wards. In Belfast County borough district, for example, there are 52 wards. There are currently 599 wards in Northern Ireland. Government officials are elected to represent several wards, and Census statistics are compiled at the ward level. For example, the 2001 Census outputs use the 582 electoral wards in existence at Census Day. All of these 582 wards had more than 100 residents/40 households.
} 
approaches described in section 4.D, since the choice of plan is likely influenced by unobserved characteristics of the home or the household that also influence usage of electricity.

The effect of feedback on log consumption, at least for those households that are on prepayment plans, is thus $\Delta=\delta_{\text {keypad }}-\delta_{\text {powercard }}$. This is equivalent to a prepayment dummy $\times$ post 2002 dummy interaction term. The proportional effect on $\mathrm{kWh}$ consumed is $\exp (\Delta)-1$.

For a "perfectly informed consumer," the effect would be zero. An effect different from zero suggests less-than-perfect information (inattention), which the meter helps correct. Since we do not know whether the customer actually checks the meter, this is an "intention to treat" effect (see Angrist and Pischke, 2009, p. 163).

\section{F. The Choice of Independent Variables}

Vector $\mathbf{x}$ in equations (2), (6) and (7) is comprised of variables that we expect to influence to the demand of electricity directly (e.g., house size, etc.) or via the cost of monitoring. It thus includes the home type (e.g., single-family, semi-detached, etc.), size (measured as the number of rooms) and age. It also includes the number of years the household has been living in this home to proxy for the household's familiarity with the energy efficiency of this dwelling and the vintage of heating and electrical equipment.

Dummies for the type of heating system and characteristics of the household (its size, number of children, number of elderly persons, number of workers, education, and whether the household is comprised of unrelated adults) are also included. Education and other household characteristics may also serve as proxies for the cost of monitoring electricity usage. Finally, an important component of $\mathbf{x}$ is the weather, which we measure as the heating degree days and cooling degree days over the three months prior to the date when the household was interviewed. 
Vector $\mathbf{Z}$ (equation 3) includes all of the above household and dwelling characteristics, plus - for identification purposes — others that might influence the choice of plan but should have no direct influence on electricity consumption. This set of "excluded variables" is comprised of whether the household owns a car, lives in the metro Belfast area, has income in the bottom $25 \%$ of the sample distribution, and has one or more members with a disability that causes serious mobility impairment, since lack of transportation may make plans that require physically going out to pay bills less attractive. It is also likely that individuals may choose a plan over another based on word of mouth or this plan's popularity with neighbors and friends. For this reason, we include in $\mathbf{Z}$ (but not in $\mathbf{x}$ ) the percentage of the other residents of the same ward in the CHS that use: (i) a prepayment plan or (ii) a direct debit plan.

\section{The Data}

Attention is restricted to those households that presumably have a reasonable degree of control over the use of energy at their premises. For this reason, we excluded from the initial sample $(\mathrm{N}=55,065)$ i) squatters and households who live at a given location rent-free, ii) households for whom the dwelling serves as a business premise, and iii) observations where the respondent refused to provide information about tenure. We also excluded iv) persons or households that rent a single-room within a house or apartment, as that is likely to capture lodgers and other types of temporary housing arrangements where the respondent has little control over fuel use and bills. Items (i)-(iv) together account for around $1 \%$ of the original sample.

Finally, we excluded observations where the most recent electricity bill is missing, those with missing information about the selected plan, and households with an electric storage heater, 
since these households would typically adopt the Economy7 tariff schedule, which makes it impossible for us to calculate the kWh used based on the CHS data. ${ }^{18}$ We further trim the bottom and top $1 \%$ of the distribution of electricity $\mathrm{kWh}$ in the sample. This leaves us with $\mathrm{N}=45,149$ usable observations for our regressions. In subsequent regressions, we further exclude households that rented their dwelling from the Housing Executive (i.e., public or assisted housing, which account for $21.77 \%$ of the original sample) or from a housing association (a private charity that provides low-cost housing: $2.40 \%$ of the original sample), which results in a sample of 34,779 observations.

Table 3, panels (B) and (C), shows the breakdown of the final two samples (with and without public housing) by year. Table 4 displays descriptive statistics about the housing units in our samples, which are comprised primarily of single-family homes (38\% and $44 \%$ ), followed by semi-detached and terraced homes (21 and 33\%, respectively).

In the sample that includes those that live in public housing, approximately $32 \%$ of the households own the home outright, $38 \%$ are paying a mortgage, and the remaining $30 \%$ rent their homes. The majority of those who rent their homes rent them from the Housing Executive (about 22\%) or from a housing association (2.39\%). Only $6.43 \%$ of the sample rent their homes from private landlords. When households who rent from the Housing Executive or a housing association are excluded from the usable sample, renters account for $6.89 \%$ of the sample and all of them rent from private landlords.

Information about heating is reported in table 5. Northern Ireland has a mild climate, with the temperature rarely higher than $75^{\circ}$ Fahrenheit $\left(24^{\circ}\right.$ Celsius), and thus little demand for air conditioning. As a consequence, much of the energy usage in the residential sector in Northern

\footnotetext{
${ }^{18}$ NIE however reports that only about $7 \%$ of the households subscribe to this tariff plan, which is effectively a time-of-use plan with nighttime prices much lower than daytime prices.
} 
Ireland is for heating. Homes are heated with coal, fuel oil, natural gas, electricity, wood or peat, as well as other non-traditional fuels. In fact, a majority of homes in our sample use more than one fuel in their home. We cannot tell for sure from the CHS which is the most important fuel, but because we eliminated from our sample households with electric storage heat and on the Economy7 plan, it is reasonable to assume that electricity was only a supplementary source of heat in our sample. ${ }^{19}$

Tables 6 and 7 present statistics on household characteristics and income, respectively. To avoid losing the observations from those households that do not report income, we create a companion missing income dummy, and recode income to zero when not reported. Income is top-coded in the CHS. Households with top-coded income are assigned the highest income class. Again, a companion "topcoded" dummy is created. All three income variables must be included in our regressions (see section 6).

Weather data are taken from several monitors in Northern Ireland available from the T3 Global Surface Summary of the Day from NOAA. Because the survey asks respondents about past energy consumption (typically quarterly), we use a three-month moving average of the heating degree days (HDD) relative to $65^{\circ} \mathrm{F}\left(18^{\circ} \mathrm{C}\right)$, as is standard practice with the US Department of Energy. The mean three-month average for HDD is $490.65{ }^{20} \mathrm{We}$ also computed

\footnotetext{
${ }^{19}$ Data from the UK Department of Energy and Climate Change show that the usage of electricity in homes with Economy 7 plans and electric storage heaters is $50 \%$ larger than its counterpart in homes with standard meters. We compared electricity usage in our sample across households that do and do not use electricity for heating purposes, and found that the difference is only $10 \%$. This brings further evidence in support of our claim that electricity is unlikely to be a main heating fuel in our sample.

${ }^{20}$ We have data from a total from 26 NOAA weather monitoring stations in Northern Ireland. For comparison purposes, we also selected the weather records from the Dublin airport, which is on the island, but is part of the Republic of Ireland. Out of the 26 Northern Ireland monitoring stations, we used 14 (5 of the remainder had been discontinued by the beginning of our study period, 3 were in ambiguous or unidentifiable locations, and 4 did not have valid temperature data). These 14 monitoring stations had data for every day of the year, and two were within the Belfast metro area. We therefore constructed daily average temperatures, and hence heating degree days for i) all of the Northern Ireland monitoring stations, ii) only the Belfast locations, and iii) only the Dublin airport monitor. The HDD based on i), ii) and iii) were very similar to one another and in fact the correlation between i) and ii) is 0.9973 , i) and ii) is 0.9897 , and ii) and iii) is 0.9939 . The regressions reported in section 6 of this paper are based on
} 
the cooling degree days, but these ended up being almost always zero, and so we do not include them in our regressions.

Energy demand should, of course, be influenced by the presence of energy efficiency investments and appliances in the home. Unfortunately, the CHS does not routinely inquire about energy-efficiency investments. The only exception is the 2008-09 CHS (the last wave of surveys we use in this paper). Based on specific questions on energy efficiency, we know that by 200809 about $83 \%$ of the homes covered by the CHS had attic insulation, $59 \%$ had cavity wall insulation, $76 \%$ had insulated the hot water tank, $56 \%$ had insulated the hot water pipes, $83 \%$ had double-paned windows, $36 \%$ had been weather-proofed, $58 \%$ had installed low-energy lightbulbs, and $15 \%$ had a programmable thermostat.

In the same wave of the CHS, the questionnaire also elicited information as to whether the respondent had availed himself of incentives and subsidies for energy efficiency investments. Only about $3 \%$ had received incentives from the Warm Homes program, and a similar share had received other incentives for attic, wall and boiler insulation. ${ }^{21}$

All homes in the CHS are served by electricity. Descriptive statistics for electricity consumption and prices are displayed in table 8. Prices are all deflated to 2009 constant British

\footnotetext{
i), but virtually identical results are obtained when we use the others. We note that - with the only exception of the Belfast metro area-we cannot assign to a household the HDD computed from the monitoring station closest to the households because we do not know where exactly the household resides.

${ }^{21}$ The Warm Homes scheme was launched in 2001 by the Department of Social Development to address fuel poverty in Northern Ireland. The scheme provides insulation measures, heating measures and energy efficient lightbulbs to people on low incomes, targeting 8,250 households every year. Heatsmart, started in April 1999 and managed by the Northern Ireland Energy Agency, provides free and independent heating and energy saving advice to tenants across Northern Ireland. Winter fuel payments were introduced in 1997 to help low-income seniors with the costs of keeping warm during the winter (People aged between 60 and 79 years receive $£ 250$ per household, and those over age 80 receive $£ 400$ ). A separate cold winter payment of $£ 25$ each week, between November 1 st and March 31st, is available when the temperature is freezing or below for any period of seven consecutive days. This extra payment is available to those low-income households receiving Pension Credit, Income Support, Income-based Jobseeker's Allowance or Income-related Employment and Support Allowance (ESA). It has been in existence since 1991.
} 
Pounds using the Real Price Index. ${ }^{22}$ We identify tariff plan exactly in the CHS data and assign marginal electricity price based on the historical tariff data in table 1 . We use the price information to calculate the $\mathrm{kWh}$ used in the last quarter by each household. ${ }^{23}$ The average household uses about $4000-4200 \mathrm{kWh}$ per year, a figure that is similar to the estimates provided by NIE.

In 2008, the average annual electricity consumption in our sample was $3931 \mathrm{kWh}$. This is in line with the average usage per standard (i.e., non-Economy7) residential meter reported by UK DECC for Northern Ireland (4188 kWh in 2008 and $3952 \mathrm{kWh}$ in 2009) and for the UK as a while (3800 kWh a year) (UK DECC, 2012c). Consumption in Britain is thus much lower than that of Sweden and Finland (where the typical household uses 7000-8000 kWh a year), France (5500 kWh/year) and the Republic of Ireland (about $5000 \mathrm{kWh} /$ year), and higher than that of Germany, the Netherlands (about $3500 \mathrm{kWh}$ a year), and Italy (about $3000 \mathrm{kWh}$ a year). ${ }^{24}$ For comparison, the average US household uses $11,480 \mathrm{kWh}$ a year, with an annual total of over 13,000 kWh at single-family homes (Energy Information Agency, 2011).

\footnotetext{
${ }^{22}$ The real price index (RPI) is compiled by the UK government: http://www.statistics.gov.uk/STATBASE/Source.asp?vlnk=1442.

${ }^{23} \mathrm{We}$ compute usage as follows. We use the nominal posted prices per $\mathrm{kWh}$ from table 1 . For the periods with constant price per kWh, we subtract the VAT (8\% in 1994-1997, and 5\% thereafter), from the reported bill. The resulting amount must be equal to the fixed fee, plus the price per $\mathrm{kWh}$ times the $\mathrm{kWh}$ used. We now solve this equation for $\mathrm{kWh}$ used. When block pricing was present, we use a similar formula, namely bill (before VAT)=fixed fee $+\mathrm{p} 1 \times \mathrm{kWh}$ if the respondent's usage falls in the first block, or bill=fixed fee $+\mathrm{p} 1 * 250+\mathrm{p} 2 *(\mathrm{kWh}-250)$, where $\mathrm{p} 1$ and $\mathrm{p} 2$ are the tariffs per $\mathrm{kWh}$ in the first and second block, respectively, and $250 \mathrm{kWh}$ per quarter is cutoff between the first and second block. If the $\mathrm{kWh}$ amount that solves the first equation exceeds $250 \mathrm{kWh}$, then we assume that the respondent's usage falls in the second block and so we obtain usage by solving the second equation. To check that these calculations were correct, we computed electricity bills for a household that uses $3300 \mathrm{kWh}$ under three alternative pricing plans (credit, direct debit and prepay), and compared them with the corresponding figures reported by the UK DECC (2012) in each year between 1990 and 2009. Our calculations match the official figures perfectly.

${ }^{24}$ See http://www.odyssee-indicators.org/reports/household/EE-trends-Household-EU-elec-S4.pdf (last accessed 27 August 2012)
} 
Information about the choice of payment plans for electricity is displayed in table 9. Combined with tables 1-2, this allows us to construct a complete picture of prices, plan features and percentage of the sample that selects each plan.

\section{Results}

\section{A. Electricity Demand}

Our first order of business to estimate the electricity demand (6), using the two-step approach described in section 4 . This approach regards price as endogenous with the choice of plan, but does not yet include plan dummies. We pool the 18 waves of the CHS and associated price and weather information, which means that we impose two sets of restrictions on the coefficients: 1) that all coefficients (including price and income elasticities) are constant over the sample period, and 2) that the price elasticity is constant across payment plans. These restrictions are necessary because of the very limited within-year variation in electricity price in Northern Ireland (see table 1). They can be checked by including year dummies and/or re-estimating the regression equations over different subset of years (see Halvorsen and Larsen, 2001, and Rapson, $2011)^{25}$

The results for three specifications of equation (6) are displayed in table 10. All of them use data from the full study period (1990-2009) and include geographic fixed effects, but omit the interview month and year dummies. All $\mathrm{t}$ statistics are based on standard errors clustered at the ward level.

Panel (A) reports the simplest specification, where the price elasticity is -0.94 and the income elasticity is 0.17 . This should be interpreted as the income elasticity conditional on

\footnotetext{
${ }^{25}$ Dubin and McFadden (1984) and Mansur et al. (2008) allow the slope of the demand function with respect to price to vary across fuel choices.
} 
knowing the income of the household. The coefficients on the missing income and top-coded dummies are positive and significant, suggesting that households that do not report their income might be wealthy or otherwise have significantly larger electricity consumption than those that do. Top earners consume $14 \%$ more than is explained by their imputed income alone. The weather does influence electricity usage: The three-month moving average of HDD is positively and significantly associated with electricity usage.

In specification (B), we add variables that describe the type of heat and other characteristics of home. In specification (C), we further add household characteristics. Adding regressors results in smaller price and income elasticities than in (A). In both (B) and (C), the coefficients on heat type are significant and intuitively appealing: Homes with electric heating use more electricity (about 14-17\% more), all else the same, and homes heated with gas, oil, wood or coal about 7-9\% less than the baseline category (all other fuel types).

Housing characteristics are likewise associated with energy consumption. Each additional room increases electricity usage significantly by 4.7-7.9\%. Semi-detached and terraced homes, which share one or more walls with a neighbor (and are therefore more insulated from cold weather), tend to use, all else the same, 9 -17\% less than single-family homes. All else the same, homes built before 1945 and homes built between 1945 and 1965 use roughly the same amount of electricity as homes built after 1985 (which is our omitted category). Homes built between 1965 and 1985 use between $2.6 \%$ and $3.9 \%$ more. These results are intuitive: Newer homes are expected to be more energy efficient; older homes may have been retrofitted or perhaps contain fewer appliances. We also note that during the $1965-85$ period there was a small construction 
boom in Northern Ireland, with homes being built quickly and inexpensively. ${ }^{26}$ Finally, consumption depends in a quadratic fashion on the time the occupants have lived in their home.

Turning to the household variables (panel (C)), the number of children is positively correlated with energy usage. Adding an adult increases usage, but at a lower rate if this adult is an elderly person. We suspect that the elderly might engage in more energy conservation and use fewer appliances than younger individuals.

Households with greater education levels and more employed persons are associated with less electricity usage. The presence of a college-educated adult implies $4.3 \%$ less usage. An additional worker implies a $2 \%$ drop in electricity consumption. These effects may be due to greater efforts to conserve energy and improve energy efficiency, or simply capture the amount of time spent in the home. Renters use less electricity than owners, most likely because they have smaller homes and fewer electricity-using devices.

In sum, the results suggest that our data are plausible and consistent with a well-behaved electricity demand function. Wald-type tests indicate that i) price and income, ii) the heating system variables, iii) dwelling characteristics, and iv) household characteristics are jointly significant. ${ }^{27}$ Wald-type tests also indicate that the correction terms are important and should be included in the model. ${ }^{28}$ We build on these demand functions to assess the effect of the keypad.

\section{B. What is the Effect of the Feedback?}

\footnotetext{
${ }^{26}$ George Hutchinson, personal communication, 14 December, 2010.

27 The Wald-type statistics are, in order, 135.67, 250.96, 158.45, and 250.96 based on run (C). They fall in the rejection region of the chi square distribution with the appropriate degrees of freedom $(2,5,9$, and 7 , respectively) at the conventional levels.

${ }^{28}$ Based on (C), the Wald-type statistic is 25.72 , which falls in the rejection region for the chi square with 8 degrees of freedom at the conventional levels.
} 
Figure 1 displays average log electricity consumption over time separately for prepayment and all other households. Figure 2 presents a similar graph for expenditure on electricity bills. The two graphs are consistent with the notion that the keypad may have played a role in reducing usage, as has been found in other settings with usage feedback.

The graph in Figure 1 shows that prepayment and all other customers were similar from 1994 until CHS wave 2002-03, when the keypad was introduced. T tests confirm that during that period the control group's log usage was undistinguishable from that of the prepayment group. Figure 1 also shows that log usage dropped for the prepayment group after CHS wave 2002-03. The other customers likewise reduced consumption (perhaps because of rising electricity prices or energy efficiency campaigns), but not quite so fast nor to the extent of the prepayment households. In fact, if we form sufficiently narrow "windows" around the introduction of the keypad event to avoid capturing long-term trends, log usage dropped for the prepayment customers, but remained virtually unchanged for the others, as is consistent with the notion that these households shouldn't be affected. ${ }^{29}$

To assess the effect of the keypad, we compare log usage for control and prepay customers before and after the introduction of the keypad (while controlling for other determinants of the demand for electricity) by running regression (7) for windows of various width. We construct six such windows. The first is 2000-2005, since we found that over that period powercard and keypad customers, who make up our treatment group, were very similar in terms of dwelling type and size, heating and household characteristics (including income, when reported, propensity to omit income, and topcoding).

\footnotetext{
${ }^{29}$ For example, focusing on a relatively small window around the adoption of the keypad (1999-2006) to avoid capturing long-term trends, log usage for pre-payment customers indeed declined from 6.87 in 1999-2002 to 6.73 in 2003-2006 ( $\mathrm{t}$ statistic 4.86), while that of "account" customers (the most popular plan) remained virtually unchanged (6.82 and 6.81, respectively, for a t statistic of 1.06 ).
} 
We then progressively increase the "window" width, focusing on 1999-2006, 1998-2007, 1997-2009 (the Peace Process was put in place in Northern Ireland in 1997, and this is the beginning of a much more economically and socially stable period for this region), 1994-2009 (since our controls are similar to the prepay households in terms of usage from 1994 to the introduction of the keypad), and the full study period (1990-2009). Broader windows contain more observations, but generally result in bigger differences in terms of dwelling and household characteristics across powercard and keypad holders, and across prepay customers and the controls.

Overall, prepay customers have smaller homes (the difference is about one room), are more likely to live terraced homes and less likely to live in a single-family or semi-detached home. They also have lower household income and are more likely to be renters than those in other plans. Prepay homes are also slightly less likely to use heating oil for heating. Our regressions, however, already control for these characteristics, as well as selection into the plan.

The regression results are reported in table 11. The regressions include plan dummies, and the omitted plan is the traditional "account" plan, the standard offer service for NIE, whereby customers are billed quarterly and pay by cash, check or through their EasySaver.

The results displayed in table 11 are striking. Usage for prepay customers before the keypad is usually no less than that of the baseline group, all else the same. By contrast, keypad customers' consumption is usually less than that that of a comparable household in the baseline group. The net effect of the keypad is consistently negative and significant - the keypad appears to have reduced electricity usage. The magnitude of this effect is progressively stronger as we expand the sample period, starting at a $10.67 \%$ reduction (standard error $3.64 \%$ ) in (A) and 
reaching a $17.68 \%$ reduction (standard error $1.32 \%)$ in $(\mathrm{F}) .{ }^{30}$ At its low end, the effect of the keypad is thus similar in magnitude to that reported in Owen and Ward (2007) and based on an initial group of 200 NIE customers.

\section{Robustness Checks}

We also re-run models (D)-(F) with the Lee and Dahl selection correction terms instead of the unrestricted Dubin-McFadden approach. For the entire study period, the Lee approach estimates the effect of the keypad to be a $16.6 \%$ reduction in consumption, whereas the Dahl approach produces slightly more modest effects (a 10.4\% reduction in usage). In runs not reported in this paper, we omitted the geographic fixed effects, finding that price and income elasticities, and the effect of the keypad, were within $5 \%$ of their counterparts from table 11.

Fischer (2008) and Darby (2010) warn that there is likely to be heterogeneity in household response to in-home usage displays. Households with very low levels of usage (due to preferences for conservation or low income) are unlikely to be able to reduce consumption even further, and may choose to improve comfort, once they realize that they are on track relative to their usual bills.

To check for this possibility, in table 12 we report the same regressions as in table 11 , but based on a sample that omits households living in public/assisted housing, who tend to be poorer. The coefficients are similar to their counterparts in table 11, and the "average treatment effect" of the introduction of the keypad ranges from a $10.45 \%$ reduction in electricity usage (specification $(\mathrm{A}))$ to a $18 \%$ reduction (specification $(\mathrm{F}))$.

\footnotetext{
${ }^{30}$ The effct is computed as described in section 4.D. The standard errors are computed using the delta method.
} 
Table 13 displays the findings from several other robustness checks. Panel (A) explores income or income measurement related issues, showing that the results in table 11 are robust to dropping lower income households, higher income households, and households that do not report income. Panel (B) of table 13 checks the effect of model specification decisions. Again, the net effect of the keypad is robust to excluding price and weather, and excluding income and other sociodemographics. We note that in the latter case the omitted income and sociodemographic terms are usually picked up by the coefficients on the selection correction terms. When the selection correction terms are not included in the model, which means that no allowance is made for the endogeneity of price and plan choice, the effect of the keypad is a little less pronounced. Finally, including year dummies, has little impact of the effect of the keypad, but results in more pronounced — even by 30 or more percent - price elasticities, a result that we attribute to the high correlation between them.

To make sure that we do not incorrectly attribute to the keypad a general decrease in electricity consumption in Northern Ireland over time, we conducted a "falsification test" on the customers not on the keypad. Specifically, we ran the regressions of equation (7) on non-keypad, non-prepay customers (i.e., our control group), with a post-2002 dummy. If the introduction of the keypad had no effect other than on keypad customers, the coefficient on this dummy should be insignificant. We find that this coefficient is positive, small (the difference in consumption varies with the sample period, but is always less than $1 \%$ ), and statistically insignificant at the conventional levels. This reinforces our result that the reduction in usage given house size, income, etc. after the introduction of the keypad is specific to a group — the prepayment groupand does not extend to the rest of the customer base. For comparison, if the same regression is 
run using a sample that is comprised only of prepayment customers, the coefficient on the post 2002 dummy is a strongly significant -0.175 .

\section{Discussion and Conclusion}

Our investigation suggests that households do respond to the provision of information by using less electricity, even accounting for type of home, heat, household characteristics and possible selection of households into pre-payment plans. This effect is quite pronounced. When attention is restricted to relatively few years around the introduction of the advanced metering device to avoid capturing long-term trends in energy usage, the effect is at $10-13 \%$ reduction in electricity usage. The effect is stronger (up to about 17-18\%) when we use the entire set of data available to us (1990-2009). Our findings provide support for earlier claims in the literature for smart metering and feedback displays (e.g. Darby 2006; Faruqui et al., 2010), and early findings from Northern Ireland (Owen and Ward, 2007), which were all based on small samples and/or short-lived pilot programs. To our knowledge, this is the first attempt to estimate the effect of information using both a large-scale experiment and a large sample.

Our data do not document how households managed to reduce usage - whether they engaged in more careful conservation behavior, unplugged appliances, cut down on usage of energy-intensive appliances or undertook energy-efficiency investments (or all of the above). Brutscher (2011) suggests that the keypad may act as a commitment device.

Darby (2010) discusses the benefits of "smart" and advanced metering. From the utilities' perspective, these systems reduce the costs of metering, billing, and investigating outages. NIE representatives generally cite lower customer support costs (Livingstone, 2011). The utility loses revenue when electricity sales are reduced, but also saves on operating costs by using smart 
meters, suggesting little or no loss of profit. ${ }^{31}$ That NIE initially planned to install 75,000 keypad meters, but now has over 250,000, would seem to be evidence of some derived benefit to the utility. Smart and advanced meters also help reduce fraud, and, when combined with demandresponse actions (such as dynamic pricing) assist with peak-load management.

An additional and important category of benefits are the savings realized by the consumer. We calculate that usage reductions like the ones documented in this paper (10-17\%) imply annual savings ranging from $£ 54.81$ to $f 93.18$ (2009 $f$ ) for the average prepay customer.

It is of interest to assess the extent of the carbon emissions reductions attributable to the advanced metering device at our study locale, and their cost. The cost of a keypad meter is comprised of the purchase and installation costs, plus the cost of operation. Owen and Ward (2007) estimate these costs to be an $£ 37-43$ (purchase and installation) and $£ 25-30$ (present value of the operating costs) per meter, respectively. ${ }^{32}$ Assuming no changes in the operating costs in the future, total per-unit costs for the life of keypad devices (assumed to be 10 years) are $£ 62-73$. Each $\mathrm{kWh}$ of grid electricity in the UK is estimated to generate $0.544 \mathrm{kgCO}_{2} \mathrm{e}$ (DEFRA, 2009).

Straightforward calculations show that it takes a $12.5 \%$ reduction from the average prepay usage (4016 kWh per year) over each of 10 years for the cost of a tonne of $\mathrm{CO}_{2} \mathrm{e}$ to be equal to the price per tonne-- $£ 25$ in 2009 — generally used by the UK government in its policy analyses and calculations; see DECC, 2009). ${ }^{33}$ Larger reductions will be even more costeffective.

\footnotetext{
${ }^{31}$ At least in the US, utilities seeking to install smart meters estimate the reductions in costs due to the smart meters to be large. See, for example, http://tinyurl.com/SMECOAMI.

${ }^{32}$ Owen and Ward (2007) base their estimates on 300,000 installed units, which is slightly more than the 250,000 installed units in NIE, but indicate that unit costs have been falling over time. On balance we find their estimates reasonable.

${ }^{33}$ The "traded" price of carbon is used for appraising policies that affect emissions in sectors covered by the EU ETS (i.e. the power sector). It is based upon estimates of future EUA and global carbon market prices. It is higher than the actual prices of Certified Emissions Reductions (CER) that can be bought and sold on the European
} 
Perusal of the results reported in tables 11 and 12 suggests that most of our estimated reductions are cost-effective, and that our most conservative estimate of the effect of the keypad barely misses the $£ 25 /$ tonne mark. The cost per ton of $\mathrm{CO}_{2} \mathrm{e}$ is $£ 28.38-33.41$ for a $10 \%$ electricity usage reduction (an effect of magnitude similar to that in specification (A) of tables 11 and 12 ), and $£ 20.30-23.90$ for a reduction of $13.98 \%$, the one in panel (B) of table 11 . The costeffectiveness of the keypad is thus comparable to that of other, more traditional abatement measures.

These calculations are performed from the point of view of the regulator. There are other environmental benefits, such as reductions in the emissions of conventional air pollutants associated with power generation, and energy security benefits associated with reduced energy usage, which we do not attempt to estimate in this paper, but that are likely to be sizeable and deserve future research.

exchange. CER contract prices in 2010 fluctuated between $€ 12$ and $€ 14$, which is approximately $f 11-12$ at the current exchange rate between the euro and the pound sterling. 


\section{References}

Allcott, Hunt (2010) "Social Norms and Energy Conservation" Unpublished Working Paper http://web.mit.edu/allcott/www/Allcott\%202010\%20\%20Social\%20Norms\%20and\%20Energy\%20Conservation.pdf

Angrist, Joshua D. and Jorn-Steffen Pischke, (2009), Mostly Harmless Econometrics: An Empiricist's Companion, Princeton, NJ: Princeton University Press.

Ayres, Ian, Sophie Raseman and Alice Shih (2009), "Evidence from Two Large Field Experiments that Peer Comparison Feedback Can Reduce Residential Energy Usage," NBER Working paper 15836, Cambridge, MA: September.

Auffhammer, Maximillian, Carl Blumstein, and Meredith Fowlie, (2008), "Demand-Side Management and Energy Efficiency Revisited", The Energy Joumat. Vol. 29, No. 3.

Bernard, Jean-Thomas, Denis Bolduc, Nadège-Désirée Yameogo. (2011), “A Pseudo-Panel Data Model of Household Electricity Demand," Resource and Energy Economics 33, (1), 315-325.

Borenstein, Severin (2009), "To What Electricity Price Do Consumers Respond? Residential Demand Elasticity Under Increasing-Block Pricing," draft manuscript, University of California, Berkeley, available www.econ.yale.edu/seminars/apmicro/am09/borenstein-090514.pdf

Bourguignon, Francois, Martin Fournier and Marc Gurgand (2007), "Selection bias corrections based on the multinomial logit model: Monte Carlo comparisons," Journal of Economic Surveys 21(1), 174-205

Boyd, Jenny (2008), "Keypad Meters: The Northern Ireland experience," http://www.ukerc.ac.uk/Downloads/PDF/Meeting\%20Place/Events/2008/05UKcanadad emandred/Boyd,\%20Jenny.pdf

Brutscher, Phillip-Bastian (2011), "Payment Matters: An Exploratory Study into Pre-Payment Electricity Metering," Cambridge EPRG Working Paper EPRG1108

Dahl, G. B. (2002), "Mobility and the Returns to Education: Testing a Roy Model with Multiple markets," Econometrica, 70, 2367-2420.

Darby, Sarah (2006), "The Effectiveness of Feedback on Energy Consumption: A Review for DEFRA of the Literature on Metering, Billing and Direct Displays," Environmental Change Institute, University of Oxford.

Darby, Sarah (2010), “Smart Metering: What Potential for Household Engagement?” Building Research and Information, 38(5), 442-457. 
Deaton, Angus (1985) "Panel Data from Time Series of Cross Sections". Journal of Econometrics, 30, 109-26.

DECC, (2009), "Carbon Valuation in UK Policy Appraisal: A Revised Approach Climate Change Economics," UK Department of Energy and Climate Change, July 2009

DEFRA (2009), “Guidelines to Defra/DECC's greenhouse Gas conversion factors for company reporting," Department for Environment Food and Rural Affairs (DEFRA), http://www.defra.gov.uk/environment/business/reporting/pdf/20090928-guidelines-ghgconversion-factors.pd

Della Vigna, Stefano and Ulrike Malmendier (2006), "Paying Not to Go to the Gym," The American Economic Review, 96(3), 694-719.

Department For Social Development Northern Ireland (2006), Ending Fuel Poverty. A Strategy for Northern Ireland, available at http://www.dsdni.gov.uk/ending_fuel_poverty__a_strategy_for_ni.pdf

Dubin, Jeffrey A. and Daniel McFadden (1984), “An Econometric Analysis of Residential Electric Appliance Holdings and Consumption," Econometrica, 52(2), 345-362.

Dulleck, Uwe, and Sylvia Kaufmann (2004), “Do Customer Information Programs Reduce Household Electricity Demand?--the Irish Program,” Energy Policy, 32(8), 1025-1032.

Ehrhardt-Martinez, Karen, et al., (2010) “Advanced Metering Initiatives and Feedback Programs: A Meta-Review for Household Electricity-Saving Opportunities," American Council for an Energy-Efficient Economy, Report No. E105

European Commission, (2010), Interpretive Note on Directive 2009/72/EC Concerning Common Rules for the Internal Market in Electricity and Directive 2009/73/EC Concerning Common Rules for the Internal Market in Natural Gas, Commission Staff Working Paper, January

Faruqui, Ahmad and Stephen S. George (2002), "The Value of Dynamic Pricing in Mass Markets," The Electricity Journal, July, 45-55.

Faruqui, Ahmad, Sanem Sergici, and Ahmed Sharif (2010), "The Impact of Informational Feedback on Energy Consumption-A Survey of the Experimental Evidence," Energy, $35,1598-1608$.

Fischer, Corinna (2008), "Feedback on Household Electricity Consumption: A Tool for Saving Energy?" Energy Efficiency, 1, 79-104. 
Gans, Will, Anna Alberini, and Alberto Longo, (2011) "Smart Meter Devices and The Effect of Feedback on Residential Electricity Consumption: Evidence from a Natural Experiment in Northern Ireland", FEEM working paper 2011.036, http://www.feem.it/userfiles/attach/2011519940254NDL2011-036.pdf

Gleerup, Maria, Anders Larsen, Soren Leth-Peterson and Mikael Togeby (2010), "The Effect of Feedback by Text Message (SMS) and Email on Household Electricity Consumption: Experimental Evidence," The Energy Journal, 31(3), 113-132.

Grubb, Michael D. (2009), "Selling to Overconfident Consumers," American Economic Review, 99(5), 1770-1807.

Halvorsen, Bente, and Bodil M. Larsen (2001), "The Flexibility of Household Electricity Demand over Time," Resource and Energy Economics, 23, 1-18.

Hartman, Raymond S., (1988), "Self-Selection Bias in the Evaluation of Voluntary Energy Conservation Programs," The Review of Economics and Statistics, 70(3)

Hassett, Kevin and Gilbert Metcalf (1993), "Energy Conservation Investment: Do Consumer Discount the Future Correctly?" Energy Policy, 12(6), 710-716.

Ito, Koichiro (2010), "Do Consumers Respond to Marginal or Average Price? Evidence from Nonlinear Electricity Pricing," draft paper, University of California, Berkeley, November.

Lambrecht, Anja and Bernd Skiera (2006), "Paying too Much and Being Happy About It: Existence, Causes, and Consequences of Tariff-Choice Biases," Journal of Marketing Research, XLIII, 212-223.

Lee, L. F. (1983), “Generalized Econometric Models with Selectivity,” Econometrica, 51, 507512.

Lijesen, Mark (2007), “The Real-Time Price of Electricity,” Energy Economics, 29, 249-258.

Livingstone, Jenny, (2011) "Fuel Poverty Interventions, A Utility Perspective” Presentation given at the International Energy Agency (IEA) Fuel Poverty Workshop, Dublin, Ireland January 28-29: www.iea.org/work/2011/poverty/pres8_LIVINGSTONE.pdf Accessed on April 5, 2011.

Loughran, David S and Jonathan Kulick, (2004), "Demand-Side Management and Energy Efficiency in the United States," The Energy Journal, 25 (1), 19-43.

Mansur, Erin T., Robert Mendelsohn, and Wendy Morrison (2008), "Climate Change Adaptation: A Study of Fuel Choice and Consumption in the U.S. Energy Sector," Journal of Environmental Economics and Management, 55(2), 175-193. 
Matsukawa, Isamu, (2005), “The Effects of Information on Residential Energy Demand For Electricity," The Energy Journal, 25(1), 1-17.

Meier, Helena and Katrin Rehdanz (2010), "Determinants of Residential Space Heating Expenditures in Great Britain," Energy Economics, 32, 949-959.

Metcalf, Gilbert and Donald Rosenthal (1995), “The 'New' View of Investment Decisions and Public Policy Analysis: An Application to Green Lights and Cold Refrigerators", Journal of Policy Analysis and Management. 14(4) 517-531.

Owen, Gill and Judith Ward (2007), "Smart Meters in Great Britain: the next steps?” Report published by Sustainability First, July, http://www.sustainabilityfirst.org.uk (last accessed 18 August 2012)

Rapson, David (2011), "Durable Goods and Long-Run Electricity Demand: Evidence form Air Conditioner Purchase Behavior," draft paper, University of California, Davis, October, available at http://www.econ.ucdavis.edu/faculty/dsrapson/Rapson_LR_electricity.pdf

Shin Jeong-Shik (1985), "Perception of Price When Price Information Is Costly: Evidence from Residential Electricity. Demand," Review of Economics and Statistics, 67(4), 591-598.

U.K. Department of Energy and Climate Change (2012), Quarterly energy prices table 2.2.3: Average annual domestic electricity bills for selected towns and cities in the UK and average unit cost, http://www.decc.gov.uk/en/content/cms/statistics/energy_stats/prices/prices.aspx (last accessed 17 January 2012).

U.K. Department of Energy and Climate Change (2012b), Regional Variation of Payment Method for Standard Electricity, http://www.decc.gov.uk/assets/decc/statistics/source/prices/qep242.xls (last accessed 17 January 2012).

U. K. DECC (2012c), Sub-national electricity consumption statistics and household energy distribution analysis for 2010 , http://www.decc.gov.uk/assets/decc/11/stats/publications/energy-trends/articles/4782subnat-electricity-cons-stats-article.pdf (last accessed 27 August 2012).

U.S. Energy Information Agency (2012), 2005 Residential Energy Consumption Survey-Detailed Tables, http://www.eia.gov/emeu/recs/recs2005/hc2005 tables/detailed_tables2005.html (accessed 17 January 2012).

Vella, Francis (1998), "Estimating Models with Sample Selection Bias: A Survey,” The Journal of Human Resources, 33(1), 127-169 
Waldman, Donald M., and Michael T. Ozog, (1996), "Natural and Incentive-Induced Conservation in Voluntary Energy Management Programs," Southern Economic Journal, 62(4)

Wolak, Frank A. (2011), "Do Residential Customers Respond to Hourly Prices? Evidence from a Dynamic Pricing Experiment," American Economic Review: Papers and Proceedings, 101(3), 83-87. 
Figure 1. Log electricity consumption: Average for prepayment (treatment) and control households (not adjusted for household characteristics) by year.

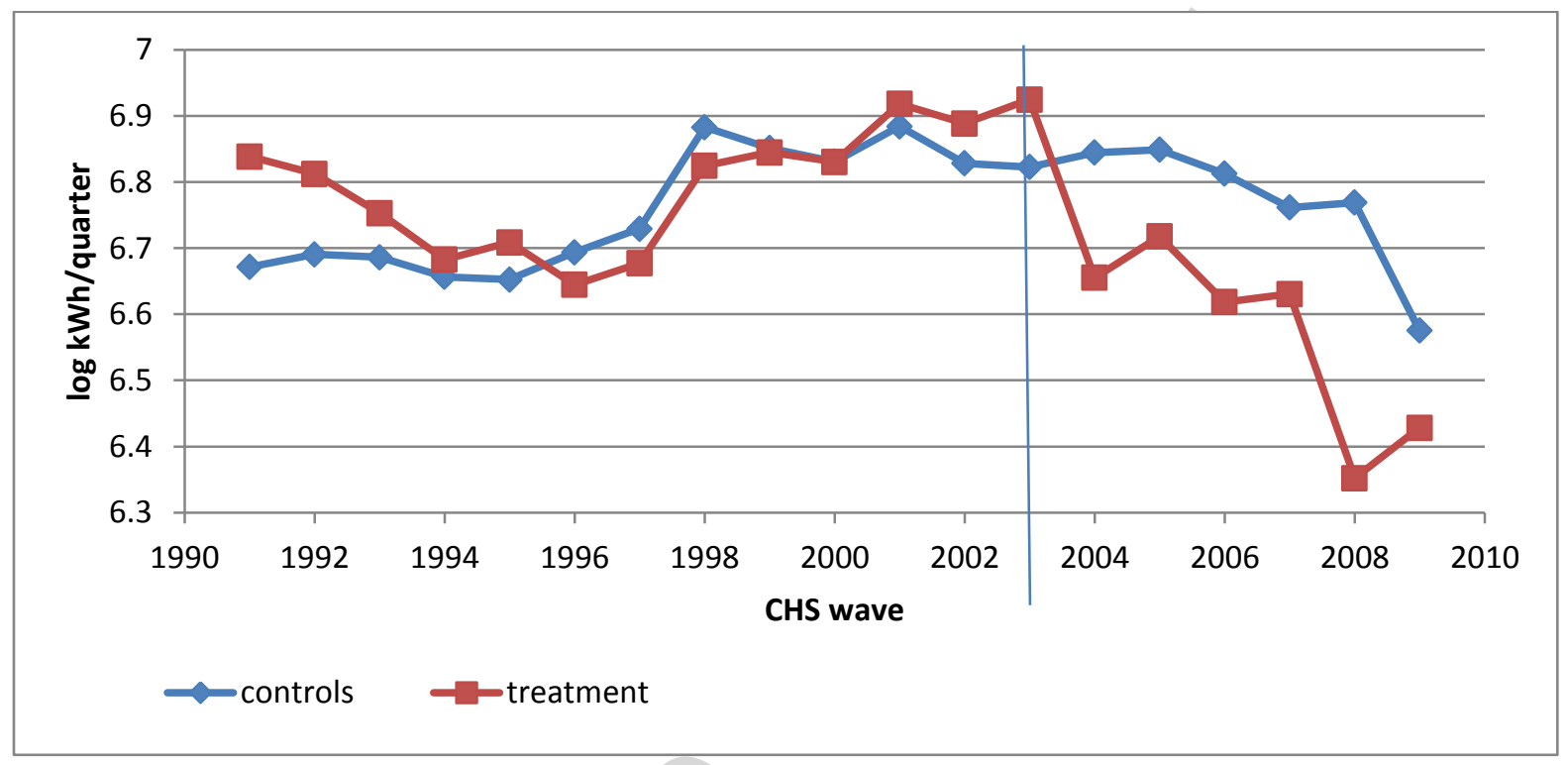


Figure. Log quarterly electricity expenditure ( $\log 2009 £)$; Average for prepayment (treatment) and control households (not adjusted for household characteristics) by year.

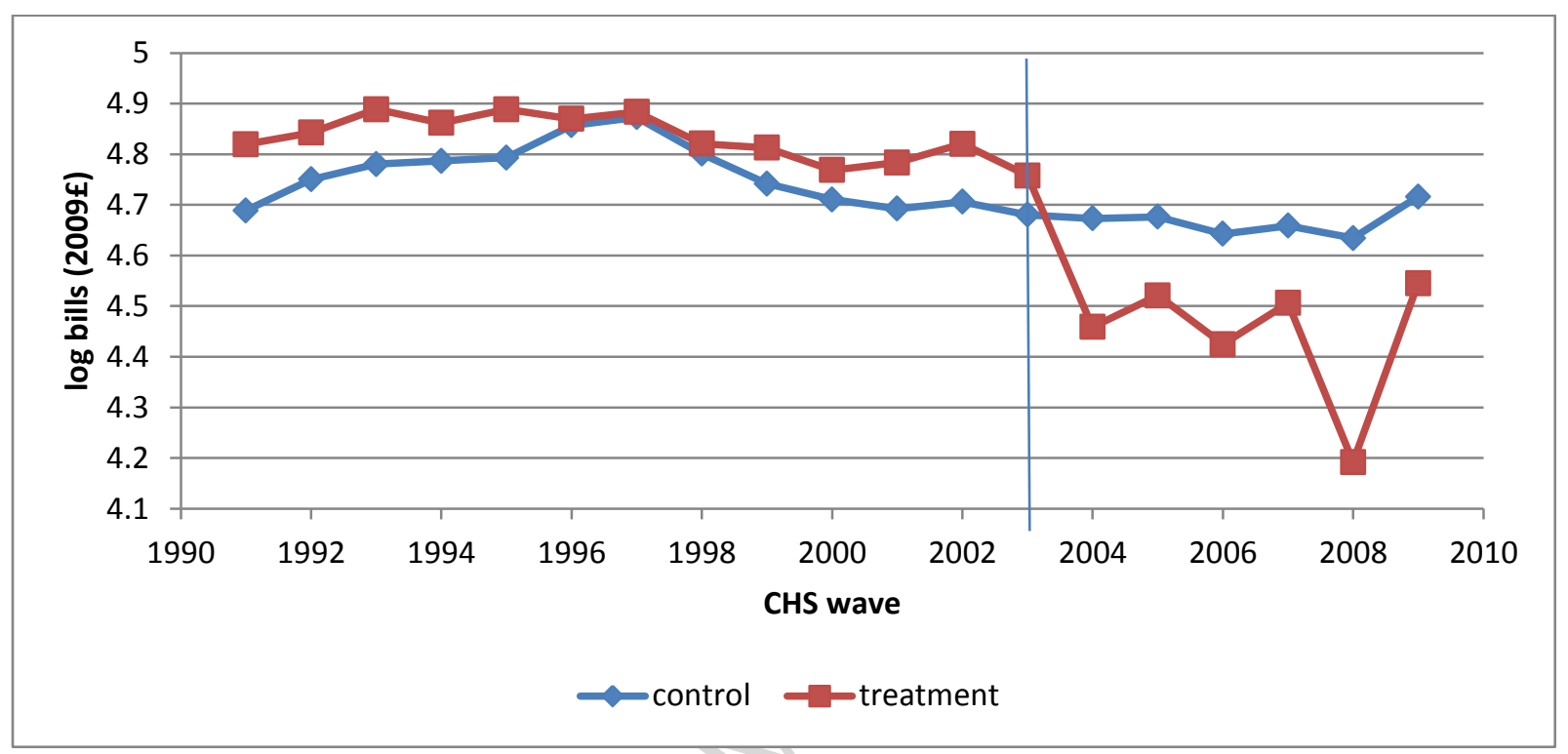


Table 1. Northern Ireland Electricity Tariffs.

\begin{tabular}{|c|c|c|c|c|}
\hline & $\begin{array}{l}\text { Standing } \\
\text { charge per } \\
\text { quarter }\end{array}$ & Unrestricted price (pence per kWh) & $\begin{array}{l}\text { Max. discount } \\
\text { per year for } \\
\text { Quarterly } \\
\text { Direct Debit } \\
\text { Plan }\end{array}$ & $\begin{array}{l}\text { Max. discount } \\
\text { per year for } \\
\text { Monthly Direct } \\
\text { Debit Plan }\end{array}$ \\
\hline Apr-90 & $£ 11.80$ & 6.84 & & \\
\hline Apr-91 & $£ 13.09$ & 7.41 & & \\
\hline Apr-92 & $£ 13.61$ & 7.71 & & \\
\hline Apr-93 & $£ 14.15$ & 7.87 & & \\
\hline Apr-94 & $£ 13.95$ & 7.75 & & \\
\hline Apr-95 & $£ 14.84$ & 8.25 & & \\
\hline Apr-96 & $£ 15.20$ & 8.45 & & \\
\hline Apr-97 & $£ 7.94$ & 9.16 first $250 \mathrm{kWh} / 8.16$ thereafter & & \\
\hline Apr-98 & $£ 7.94$ & 9.16 first $250 \mathrm{kWh} / 8.16$ thereafter & & \\
\hline Apr-99 & & 9.00 & & \\
\hline Apr-00 & & 8.60 & & \\
\hline Apr-01 & & 9.38 & & \\
\hline Apr-02 & & 9.38 & $£ 5.0$ & $£ 10.0$ \\
\hline Apr-03 & & 9.38 & $£ 14.0$ & $£ 28.0$ \\
\hline Apr-04 & & 9.64 & $£ 14.0$ & $£ 28.0$ \\
\hline Apr-05 & & 9.95 & $£ 14.0$ & $£ 28.0$ \\
\hline Apr-06 & & 11.02 & $£ 14.0$ & $£ 28.0$ \\
\hline Apr-07 & & 10.69 & $£ 14.0$ & $£ 28.0$ \\
\hline Nov-07 & & 11.11 & $£ 22.0$ & $£ 34.0$ \\
\hline Jul-08 & & 12.66 & $£ 22.0$ & $£ 34.0$ \\
\hline Oct-08 & & 16.88 & $£ 26.0$ & $£ 40.0$ \\
\hline Jan-09 & & 15.06 & $£ 26.0$ & $£ 40.0$ \\
\hline Oct-09 & & 14.31 & $£ 26.0$ & $£ 40.0$ \\
\hline Oct-10 & 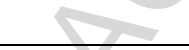 & 14.31 & $£ 26.0$ & $£ 40.0$ \\
\hline
\end{tabular}

Notes:

Prices exclude VAT. Domestic VAT of $8 \%$ was introduced in 1994 and was changed to $5 \%$ in 1997 where it has remained until now.

Discounts are $4 \%$ for monthly direct debit, and $2.5 \%$ for quarterly direct debit, up to the maximum total shown in the table.

Keypad metering was introduced in April 2002 with a discount (uncapped) of $2.5 \%$ to the standard domestic tariffs. 
Table 2. Discounts offered to specific electricity plans in Northern Ireland.

\begin{tabular}{|c|c|c|c|c|c|c|}
\hline $\begin{array}{l}\text { Acronym } \\
\text { used in } \\
\text { this } \\
\text { paper }\end{array}$ & name & since & discount & $\begin{array}{l}\text { max discount } \\
\text { per year }(£)\end{array}$ & $\begin{array}{l}\text { frequency of } \\
\text { payment }\end{array}$ & $\begin{array}{l}\text { conditions for extending } \\
\text { the discount }\end{array}$ \\
\hline & $\begin{array}{l}\text { Easy } \\
\text { Saver }\end{array}$ & April 1997 & $1.50 \%$ & 10 & unspecified & $\begin{array}{l}\text { if balance in the account } \\
\text { is no more than } £ 10 \text { or } \\
10 \% \text { of the total bill }\end{array}$ \\
\hline BUDGE & Budget & $\begin{array}{l}\text { 1970s, } \\
\text { discounts } \\
\text { since } 1997\end{array}$ & $1.50 \%$ & 10 & $\begin{array}{l}\text { regular, even } \\
\text { payments, } \\
\text { usually weekly- } \\
\text { monthly }\end{array}$ & $\begin{array}{l}\text { if balance in the account } \\
\text { is no more than } £ 10 \text { or } \\
10 \% \text { of the total bill }\end{array}$ \\
\hline DDM & $\begin{array}{l}\text { Direct } \\
\text { Debit } \\
\text { Monthly }\end{array}$ & April 2002 & $4 \%$ & $\begin{array}{l}40 \text { at } \\
\text { present. Has } \\
\text { changed over } \\
\text { the years-- } \\
\text { see table } 1 .\end{array}$ & $\begin{array}{l}\text { even monthly } \\
\text { payments }\end{array}$ & \\
\hline $\mathrm{DDQ}$ & $\begin{array}{l}\text { Direct } \\
\text { Debit } \\
\text { Quarterly }\end{array}$ & April 2002 & $2.50 \%$ & $\begin{array}{l}26 \text { at } \\
\text { present. Has } \\
\text { changed over } \\
\text { the years-- } \\
\text { see table } 1\end{array}$ & $\begin{array}{l}\text { even quarterly } \\
\text { payments }\end{array}$ & \\
\hline Keypad & Keypad & April 2002 & $2.50 \%$ & uncapped & prepay & \\
\hline
\end{tabular}


Table 3. Composition of the sample by year.

\begin{tabular}{|r|r|r|r|r|r|r|}
\cline { 2 - 8 } \multicolumn{1}{c|}{} & \multicolumn{2}{c|}{$\begin{array}{c}\text { (A) Full CHS, all } \\
\text { years }\end{array}$} & $\begin{array}{c}\text { (B) Sample used in } \\
\text { this paper } \\
\text { (electricity } \\
\text { regressions) }\end{array}$ & \multicolumn{2}{c|}{$\begin{array}{c}\text { (C) Excluding } \\
\text { Housing Executive }\end{array}$} \\
\hline year & N & percent & N & Percent & N & Percent \\
\hline 1991 & 3,166 & 5.75 & 2,862 & 6.34 & 1,976 & 5.68 \\
\hline 1992 & 3,107 & 5.64 & 2,799 & 6.2 & 1,885 & 5.42 \\
\hline 1993 & 3,097 & 5.62 & 2,557 & 5.66 & 1,755 & 5.05 \\
\hline 1994 & 3,182 & 5.78 & 2,760 & 6.11 & 1,927 & 5.54 \\
\hline 1995 & 3,220 & 5.85 & 2,823 & 6.25 & 1,990 & 5.72 \\
\hline 1996 & 3,221 & 5.85 & 2,752 & 6.09 & 2,023 & 5.82 \\
\hline 1997 & 2,892 & 5.25 & 2,467 & 5.46 & 1,808 & 5.2 \\
\hline 1998 & 3,024 & 5.49 & 2,554 & 5.66 & 1,944 & 5.59 \\
\hline 1999 & 2,809 & 5.1 & 2,364 & 5.24 & 1,790 & 5.15 \\
\hline 2000 & 3,039 & 5.52 & 2,579 & 5.71 & 1,972 & 5.67 \\
\hline 2001 & 2,800 & 5.08 & 2,350 & 5.2 & 1,821 & 5.24 \\
\hline 2002 & 2,806 & 5.1 & 2,342 & 5.19 & 1,901 & 5.47 \\
\hline 2003 & 2,787 & 5.06 & 2,242 & 4.97 & 1,836 & 5.28 \\
\hline 2004 & 2,769 & 5.03 & 2,091 & 4.63 & 1,798 & 5.17 \\
\hline 2005 & 2,773 & 5.04 & 2,059 & 4.56 & 1,769 & 5.09 \\
\hline 2006 & 2,603 & 4.73 & 1,967 & 4.36 & 1,713 & 4.93 \\
\hline 2007 & 2,726 & 4.95 & 1,904 & 4.22 & 1,652 & 4.75 \\
\hline 2008 & 2,567 & 4.66 & 1,914 & 4.24 & 1,699 & 4.89 \\
\hline 2009 & 2,476 & 4.5 & 1,766 & 3.91 & 1,520 & 4.37 \\
\hline & & & & & & 100 \\
\hline Total & 55,064 & 100 & 45,152 & 100 & 34,779 & \\
\hline & & & & & & \\
\hline
\end{tabular}


Table 4. Characteristics of the Home: Descriptive Statistics

\begin{tabular}{|c|c|c|c|c|c|c|c|}
\hline \multirow[b]{2}{*}{ Variable } & \multirow[b]{2}{*}{ Description } & \multicolumn{3}{|c|}{ (A) Full Sample } & \multicolumn{3}{|c|}{$\begin{array}{l}\text { (B) Excluding Housing } \\
\text { Executive }\end{array}$} \\
\hline & & Obs & Mean & Dev. & Obs & Mean & $\begin{array}{l}\text { Std. } \\
\text { Dev. }\end{array}$ \\
\hline SFhome & $\begin{array}{l}\text { Single-family (detached) } \\
\text { home dummy }\end{array}$ & 45152 & 0.387 & & 34779 & 0.491 & 0.500 \\
\hline SDhome & $\begin{array}{l}\text { Semi-detached home } \\
\text { dummy }\end{array}$ & 45152 & 0.215 & .411 & 34779 & 0.243 & 0.429 \\
\hline terracehome & terraced home dummy & 45152 & 0.330 & 0.470 & 34779 & 0.234 & 0.424 \\
\hline totroom & total number of rooms & 45151 & 6.793 & 1.865 & 34778 & 7.154 & 1.900 \\
\hline h_1945 & built before 1945 dummy & 45152 & 0.139 & 0.346 & 34779 & 0.167 & 0.373 \\
\hline h_1945_65 & built 1945-65 dummy & 45152 & 0.156 & 0.363 & 34779 & 0.153 & 0.360 \\
\hline h_1965_85 & built 1965-85 dummy & 45152 & 0.315 & 0.465 & 34779 & 0.279 & 0.449 \\
\hline
\end{tabular}

Table 5. Heating: Descriptive Statistics

\begin{tabular}{l|l|ccc|ccc|}
\multicolumn{2}{l|}{} & \multicolumn{3}{c|}{ (A) Full Sample } & \multicolumn{3}{c|}{ (B) Excluding Housing } \\
Executive
\end{tabular}


Table 6. Household Characteristics: Descriptive Statistics

\begin{tabular}{|c|c|c|c|c|c|c|c|}
\hline \multirow[b]{2}{*}{ Variable } & \multirow[b]{2}{*}{ Description } & \multicolumn{3}{|c|}{ (A) Full Sample } & \multicolumn{3}{|c|}{$\begin{array}{l}\text { (B) Excluding Housing } \\
\text { Executive }\end{array}$} \\
\hline & & Obs & Mean & $\begin{array}{l}\text { Std. } \\
\text { Dev. }\end{array}$ & Obs & Mean & $\begin{array}{l}\text { Std. } \\
\text { Dev. }\end{array}$ \\
\hline numadult & $\begin{array}{l}\text { Number of adults in } \\
\text { household }\end{array}$ & 45152 & 2.022 & 0.959 & 34779 & 2.130 & 0.956 \\
\hline ndepkids & $\begin{array}{l}\text { number of children } 18 \text { or } \\
\text { younger ... }\end{array}$ & 45143 & 0.770 & & 34772 & 0.773 & 1.169 \\
\hline renter & $\begin{array}{l}\text { household rents the home } \\
\text { (dummy)................. }\end{array}$ & 45152 & 0.053 & 24 & 34779 & 0.069 & 0.253 \\
\hline nelderly & $\begin{array}{l}\text { number of household } \\
\text { members } 65 \text { and older.... }\end{array}$ & 4515 & 0.350 & 0.622 & 34778 & 0.337 & 0.627 \\
\hline nworkers & $\begin{array}{l}\text { number of household } \\
\text { members who work.......... }\end{array}$ & 4495 & & 0.600 & 34610 & 0.216 & 0.636 \\
\hline college & $\begin{array}{l}\text { household member has } \\
\text { attended college } \\
\text { (dummy)... }\end{array}$ & 45152 & 0.110 & 0.314 & 34779 & 0.136 & 0.343 \\
\hline students & $\begin{array}{l}\text { unrelated adults, probably } \\
\text { students... }\end{array}$ & 45152 & 0.047 & 0.213 & 34779 & 0.059 & 0.235 \\
\hline
\end{tabular}

Table 7. Household Income: Descriptive Statistics

\begin{tabular}{c|c|ccc|ccc|}
\multicolumn{2}{l|}{} & \multicolumn{3}{c|}{ (A) Full Sample } & \multicolumn{3}{c|}{ (B) Excluding Housing } \\
Executive
\end{tabular}


Table 8. Electricity Demand and Price

\begin{tabular}{l|l|ccc|ccc|}
\multicolumn{2}{l|}{} & \multicolumn{3}{|c|}{ (A) Full Sample } & \multicolumn{3}{c|}{$\begin{array}{c}\text { (B) Excluding Housing } \\
\text { Executive }\end{array}$} \\
\hline Variable & Description & Obs & Mean & $\begin{array}{c}\text { Std. } \\
\text { Dev. }\end{array}$ & Obs & Mean & $\begin{array}{c}\text { Std. } \\
\text { Dev. }\end{array}$ \\
\hline kwh & $\begin{array}{l}\text { electricity usage } \\
\text { (kwh per quarter) }\end{array}$ & 45152 & 996.45 & 544.61 & 34779 & 1045.59 & 549.12 \\
electprice_r & $\begin{array}{l}\text { marginal price (f } \\
\text { per kWh, 2009 f) }\end{array}$ & 45152 & 0.115 & 0.01 & 34779 & 0.115 & 0.008 \\
Ikwh & In kWh & 45152 & 6.754 & 0.57 & 34779 & 6.814 & 0.547 \\
Imargprice_r & In electprice & 45152 & -2.166 & 0.06 & 34779 & -2.166 & 0.067
\end{tabular}

Table 9. Choice of Electricity Plan: Frequencies.

\begin{tabular}{|c|c|c|c|c|c|c|}
\hline decision & $\begin{array}{l}\text { Acronym and } \\
\text { Description }\end{array}$ & & \multicolumn{2}{|c|}{ (A) Full Sample } & \multicolumn{2}{|c|}{$\begin{array}{l}\text { (B) Excluding } \\
\text { Housing Executive }\end{array}$} \\
\hline 1 & $\begin{array}{l}\text { Account (incl. } \\
\text { EasySaver \& Cash) }\end{array}$ & $\begin{array}{l}\text { Mostly unrestricted } \\
\text { tariff }\end{array}$ & 33,518 & 74.23 & 26,645 & 76.61 \\
\hline 2 & DDM & See tables 1 and 2 & 4,012 & 8.89 & 3,803 & 10.93 \\
\hline 3 & DDQ & See tables 1 and 2 & 304 & 0.67 & 269 & 0.77 \\
\hline 4 & Budget Account & See tables 1 and 2 & 1,986 & 4.4 & 1,567 & 4.51 \\
\hline 5 & DHSS & Unrestricted tariff & 492 & 1.09 & 195 & 0.56 \\
\hline 6 & Powercard & Unrestricted tariff & 3,158 & $10.12 *$ & 1,229 & $5.39 *$ \\
\hline 7 & Keypad & See tables 1 and 2 & 1,682 & $12.06 *$ & 1,071 & $8.93^{*}$ \\
\hline Total & $\nabla$ & & 45,152 & 100 & 34,779 & 100 \\
\hline
\end{tabular}

* =for those years when such option existed. 
Table 10. Electricity Demand: Effect of Price, Income, House and Household Characteristics. Dep. Var.: ln kWh per quarter. T statistics in parentheses. CHANGE FOR D-F

\begin{tabular}{|c|c|c|c|}
\hline & $\begin{array}{c}(\mathrm{A}) \\
\text { weather } \\
\text { price }\end{array}$ & $\begin{array}{c}(\mathrm{B})+ \\
\text { Dheater }\end{array}$ & $\begin{array}{l}\text { (C) }+ \text { hhold } \\
\text { char }\end{array}$ \\
\hline \multirow{2}{*}{ Constant } & 1.8990 & 1.9542 & 2.8509 \\
\hline & (9.4550) & $(9.7133)$ & $(15.805)$ \\
\hline \multirow{2}{*}{ In price (2009 GBP) } & -0.9356 & -0.6945 & -0.7450 \\
\hline & $(-18.219)$ & $(-13.032)$ & $(-14.812)$ \\
\hline \multirow{2}{*}{ recodedlinc_r } & 0.1702 & 0.1352 & 0.03784 \\
\hline & (25.059) & (24.997) & (7.6829) \\
\hline \multirow{2}{*}{ incomemissing } & 1.7666 & 1.4210 & 0.4426 \\
\hline & $(27.633)$ & $(28.078)$ & (9.4714) \\
\hline \multirow{2}{*}{ topcoded } & 0.1062 & 0.02938 & 0.04728 \\
\hline & (14.039) & (3.8493) & (6.8774) \\
\hline \multirow{2}{*}{ IHDD } & 0.01967 & 0.03666 & 0.02898 \\
\hline & (4.1049) & (7.2735) & $(5.9628)$ \\
\hline \multirow{5}{*}{ gasheat } & & -0.09333 & -0.07016 \\
\hline & & $(-10.361)$ & $(-8.4479)$ \\
\hline & & -0.06973 & -0.05130 \\
\hline & & $(-8.3231)$ & $(-6.2901)$ \\
\hline & & -0.06838 & -0.07499 \\
\hline woodheat & & $(-9.2859)$ & $(-12.476)$ \\
\hline \multirow{4}{*}{ electheat } & & -0.07946 & -0.09425 \\
\hline & & $(-9.5942)$ & $(-11.505)$ \\
\hline & & 0.1340 & 0.1616 \\
\hline & & $(29.603)$ & (34.649) \\
\hline \multirow{2}{*}{$\begin{array}{l}\text { Ward Effects } \\
\text { Heating Type }\end{array}$} & Yes & Yes & Yes \\
\hline & No & Yes & Yes \\
\hline \multirow{2}{*}{ Dwelling Chars } & No & Yes & Yes \\
\hline & No & No & Yes \\
\hline $\begin{array}{l}\text { Household Chars } \\
\text { R-squared }\end{array}$ & 0.1442 & 0.2119 & 0.2983 \\
\hline N.of cases & 45149 & 45121 & 44917 \\
\hline
\end{tabular}

Dwelling characteristics omitted from the table include home type, house age, number of rooms. Household characteristics omitted from the table include number of adults, dependent children, elderly, and workers in the household, how long the household has lived in this home (duration), duration squared, a college education dummy, renter dummies, and a student house dummy. Full regression results are available upon request from the authors. 
Table 11. Electricity Demand: Effect of Price, Income, House and Household Characteristics. Dep. Var.: ln kWh per quarter.

\begin{tabular}{|c|c|c|c|c|c|c|}
\hline & $\begin{array}{l}\text { (A) } 2000- \\
2005\end{array}$ & $\begin{array}{l}\text { (B) 1999- } \\
2006\end{array}$ & $\begin{array}{l}\text { (C) } 1998- \\
2007\end{array}$ & $\begin{array}{l}\text { (D) 1997- } \\
2009\end{array}$ & $\begin{array}{l}\text { (E) 1994- } \\
2009\end{array}$ & $\begin{array}{l}\text { (F) 1990- } \\
2009\end{array}$ \\
\hline \multirow{2}{*}{ Constant } & 3.8171 & 4.1357 & 4.1404 & 3.3099 & 2.6375 & 2.8114 \\
\hline & $(9.7041)$ & $(11.828)$ & $(12.402)$ & (13.395) & $(12.756)$ & (15.444) \\
\hline \multirow{2}{*}{ In price (2009 GBP) } & -0.4956 & -0.5146 & -0.4498 & -0.6542 & -0.7836 & -0.7187 \\
\hline & $(-4.2010)$ & $(-5.8312)$ & $(-4.5574)$ & $(-11.563)$ & $(-14.315)$ & $(-13.883)$ \\
\hline \multirow{2}{*}{ recodedlinc_r $r$} & 0.03248 & 0.03827 & 0.03404 & 0.04226 & 0.03513 & 0.04477 \\
\hline & $(2.7982)$ & $(4.1269)$ & $(4.1811)$ & (5.6129) & $(5.6300)$ & (9.0386) \\
\hline \multirow{2}{*}{ incomemissing } & 0.4079 & 0.4431 & 0.3873 & 0.4742 & 0.4195 & 0.5063 \\
\hline & $(3.6230)$ & $(5.0670)$ & $(5.1708)$ & (6.7818) & $(7.0068)$ & (10.824) \\
\hline \multirow{2}{*}{ topcoded } & 0.07235 & 0.05159 & 0.05395 & 0.05844 & 0.04780 & 0.04523 \\
\hline & $(4.9989)$ & (3.6395) & (4.4309) & $(5.7802)$ & (7.1341) & (6.6474) \\
\hline \multirow{2}{*}{ IHDD } & 0.05288 & 0.04761 & 0.05241 & 0.05540 & 0.04627 & 0.02946 \\
\hline & $(6.5165)$ & $(6.6427)$ & (8.1941) & (9.4691) & $(9.3800)$ & $(6.2601)$ \\
\hline \multirow{2}{*}{ gasheat } & -0.06491 & -0.07160 & -0.07331 & -0.07935 & -0.05620 & -0.06204 \\
\hline & & $(-6.0195)$ & $(-6.8326)$ & $(-7.6942)$ & $(-6.5488)$ & $(-7.6933)$ \\
\hline \multirow{2}{*}{ oilheat } & & -0.09075 & -0.08286 & -0.06150 & -0.03908 & -0.03982 \\
\hline & 20) & $(-8.2518)$ & $(-8.4579)$ & $(-6.7918)$ & $(-4.3197)$ & $(-4.8941)$ \\
\hline \multirow{2}{*}{ woodheat } & -0.04762 & -0.04744 & -0.05985 & -0.05480 & -0.07079 & -0.07492 \\
\hline & $(-3.1963)$ & $(-4.3112)$ & $(-5.3786)$ & $(-4.8861)$ & $(-9.2184)$ & $(-12.486)$ \\
\hline \multirow{2}{*}{ coalheat } & -0.08011 & -0.07658 & -0.06609 & -0.06589 & -0.07509 & -0.09815 \\
\hline & $(-6.7115)$ & $(-7.2879)$ & $(-7.3314)$ & $(-7.0342)$ & $(-9.0025)$ & $(-12.076)$ \\
\hline \multirow{4}{*}{$\begin{array}{c}\text { electheat } \\
\text { DDM }\end{array}$} & 0.1115 & 0.1131 & 0.1166 & 0.1257 & 0.1556 & 0.1631 \\
\hline & $(15.314)$ & (19.310) & $(20.557)$ & $(24.075)$ & (31.137) & (34.176) \\
\hline & -0.02442 & -0.05862 & -0.06723 & -0.07057 & -0.05533 & -0.04918 \\
\hline & $(-1.2876)$ & $(-3.7530)$ & $(-4.7269)$ & $(-5.0203)$ & $(-4.1583)$ & $(-3.8616)$ \\
\hline \multirow{2}{*}{ DDQ } & -0.03819 & -0.1185 & -0.09230 & -0.06657 & -0.07436 & -0.04914 \\
\hline & $(-0.4381)$ & $(-1.3770)$ & $(-1.2175)$ & $(-1.0634)$ & $(-1.1868)$ & $(-1.1685)$ \\
\hline \multirow{2}{*}{ budge } & 0.03186 & 0.003279 & 0.01358 & 0.02259 & 0.03068 & 0.05381 \\
\hline & $(0.8550)$ & $(0.1075)$ & $(0.4517)$ & $(0.7702)$ & (1.1508) & (2.3195) \\
\hline \multirow{2}{*}{ powercard } & 0.05310 & 0.03064 & 0.02113 & 0.02840 & 0.04145 & 0.06538 \\
\hline & $(2.3043)$ & (1.5839) & (1.1069) & (1.2894) & $(2.0751)$ & (3.2433) \\
\hline \multirow{2}{*}{ keypad } & -0.05979 & -0.1200 & -0.1098 & -0.1401 & -0.1373 & -0.1292 \\
\hline & $(-1.7734)$ & $(-4.7720)$ & $(-5.3951)$ & $(-7.2490)$ & $(-6.8399)$ & (-6.1989) \\
\hline \multirow{2}{*}{ DHSS } & -0.08706 & -0.1530 & -0.1101 & -0.08155 & -0.01576 & 0.05920 \\
\hline & $(-1.5314)$ & $(-2.6741)$ & $(-1.9454)$ & $(-1.8335)$ & $(-0.3962)$ & (1.4512) \\
\hline Effect of the keypad & -0.1067 & -0.1398 & -0.1226 & -0.155 & -0.1787 & -0.1768 \\
\hline Standard error around effect on usage & 0.0364 & $2.82 \$$ & 0.028 & 0.024 & 0.0131 & 0.0132 \\
\hline
\end{tabular}




\begin{tabular}{lcccccc} 
Ward Effects & Yes & Yes & Yes & Yes & Yes & Yes \\
Heating Type & Yes & Yes & Yes & Yes & Yes & Yes \\
Dwelling Chars & Yes & Yes & Yes & Yes & Yes & Yes \\
Household Chars & Yes & Yes & Yes & Yes & Yes & Yes \\
R-squared & 0.3089 & 0.2984 & 0.2909 & 0.2887 & 0.2990 & 0.3014 \\
N.of cases & 13591 & 17918 & 22301 & 28444 & 36732 & 44917 \\
\hline
\end{tabular}

Dwelling characteristics omitted from the table include home type, house age, number of rooms. Household characteristics omitted from the table include number of adults, dependent children, elderly, and workers in the household, how long the household has lived in this home (duration), duration squared, a college education dummy, renter dummies, and a student house dummy. Full regression results are available upon request from the authors. 
Table 11. Electricity Demand excluding Housing Executive and Housing Association renters. Dep. Var.: $\ln \mathrm{kWh}$ per quarter

\begin{tabular}{|c|c|c|c|c|c|c|}
\hline & $\begin{array}{l}\text { (A) } 2000- \\
2005\end{array}$ & $\begin{array}{l}\text { (B) 1999- } \\
2006\end{array}$ & $\begin{array}{c}\text { (C) } 1998- \\
2007\end{array}$ & $\begin{array}{l}\text { (D) } 1997- \\
2009\end{array}$ & $\begin{array}{c}\text { (E) 1994- } \\
2009\end{array}$ & $\begin{array}{c}\text { (F) } 1900- \\
2009\end{array}$ \\
\hline \multirow{2}{*}{ Constant } & 3.9839 & 4.5083 & 4.3661 & 3.5642 & 2.5869 & 2.8371 \\
\hline & (7.447) & $(8.858)$ & (9.637) & (12.819) & $(10.437)$ & $(12.398)$ \\
\hline \multirow{2}{*}{ In price (2009 GBP) } & -0.4908 & -0.4956 & -0.4517 & -0.6540 & -0.7268 & -0.6744 \\
\hline & $(-2.943)$ & $(-3.885)$ & $(-3.636)$ & $(-10.483)$ & $(-12.385)$ & $(-11.769)$ \\
\hline \multirow{2}{*}{ recodedlinc_r } & 0.0122 & 0.0123 & 0.0130 & 0.0217 & 0.0267 & 0.0348 \\
\hline & (1.101) & $(1.216)$ & $(1.494)$ & $(2.768)$ & $(3.612)$ & $(4.956)$ \\
\hline \multirow{2}{*}{ incomemissing } & 0.2149 & 0.1912 & 0.1887 & 0.2671 & 0.3437 & 0.4210 \\
\hline & $(2.001)$ & $(2.045)$ & (2.369) & (3.773) & $(4.948)$ & (6.305) \\
\hline \multirow{2}{*}{ topcoded } & 0.0827 & 0.0667 & 0.0659 & 0.0689 & 0.0520 & 0.0503 \\
\hline & (5.376) & $(4.458)$ & $(5.151)$ & (6.142) & $(6.565)$ & (6.486) \\
\hline \multirow{2}{*}{ IHDD } & 0.0496 & 0.0451 & 0.0504 & 0.0538 & 0.0507 & 0.0376 \\
\hline & (6.145) & (6.393) & $(8.207)$ & (9.775) & $(10.596)$ & (7.993) \\
\hline \multirow{2}{*}{ gasheat } & -0.0457 & -0.0478 & -0.0573 & -0.0539 & -0.0349 & -0.0441 \\
\hline & $(-3.007)$ & $(-3.551)$ & $(-4.747)$ & $(-4.546)$ & $(-3.401)$ & $(-4.688)$ \\
\hline \multirow{2}{*}{ oilheat } & -0.0650 & -0.0580 & -0.0588 & -0.0403 & -0.0091 & -0.0130 \\
\hline & $(-4.427)$ & $(-4.737)$ & $(-6.541)$ & $(-5.045)$ & $(-1.227)$ & $(-2.025)$ \\
\hline \multirow{2}{*}{ woodheat } & -0.0265 & -0.0289 & -0.0442 & -0.0345 & -0.0432 & -0.0492 \\
\hline & $(-1.966)$ & $(-2.629)$ & $(-3.995)$ & $(-3.429)$ & $(-6.529)$ & $(-7.896)$ \\
\hline \multirow{2}{*}{ coalheat } & -0.0447 & -0.0405 & -0.0283 & -0.0326 & -0.0326 & -0.0487 \\
\hline & $(-4.267)$ & $(-4.053)$ & $(-3.273)$ & $(-3.748)$ & $(-4.539)$ & $(-7.358)$ \\
\hline \multirow{2}{*}{ electheat } & 0.0808 & 0.0803 & 0.0841 & 0.0921 & 0.1139 & 0.1222 \\
\hline & (9.344) & (11.483) & $(11.580)$ & (14.581) & (17.697) & (21.576) \\
\hline \multirow{2}{*}{ DDM } & -0.0258 & -0.0639 & -0.0865 & -0.1018 & -0.1051 & -0.1051 \\
\hline & $(-1.055)$ & $(-3.174)$ & $(-4.938)$ & $(-5.888)$ & $(-5.936)$ & $(-6.387)$ \\
\hline \multirow{2}{*}{ DDQ } & -0.0027 & -0.0732 & -0.0921 & -0.1256 & -0.1769 & -0.1647 \\
\hline & $(-0.025)$ & $(-0.773)$ & $(-1.101)$ & $(-1.737)$ & $(-2.442)$ & $(-3.274)$ \\
\hline \multirow{2}{*}{ budge } & 0.0179 & -0.0155 & -0.0274 & -0.0458 & -0.0588 & -0.0484 \\
\hline & $(0.386)$ & $(-0.414)$ & $(-0.775)$ & $(-1.260)$ & $(-1.744)$ & $(-1.670)$ \\
\hline \multirow{2}{*}{ powercard } & 0.0525 & 0.0229 & -0.0101 & -0.0260 & -0.0513 & -0.0348 \\
\hline & (1.528) & $(0.760)$ & $(-0.367)$ & $(-0.795)$ & $(-1.558)$ & $(-1.140)$ \\
\hline \multirow{2}{*}{ keypad } & -0.0578 & -0.1094 & -0.1520 & -0.2163 & -0.2382 & -0.2381 \\
\hline & $(-1.344)$ & $(-3.037)$ & $(-4.254)$ & $(-7.953)$ & $(-8.285)$ & $(-8.359)$ \\
\hline \multirow{2}{*}{ DHSS } & -0.2098 & -0.2741 & -0.2855 & -0.2886 & -0.3137 & -0.2950 \\
\hline & $(-2.239)$ & $(-3.615)$ & $(-4.472)$ & $(-5.602)$ & $(-6.866)$ & $(-6.528)$ \\
\hline Effect of the keypad & $-10.45 \%$ & $-12.39 \%$ & $-13.23 \%$ & $-17.33 \%$ & $-17.04 \%$ & $-18.40 \%$ \\
\hline Std err around the effect & $3.06 \%$ & $2.68 \%$ & $3.08 \%$ & $2.35 \%$ & $2.25 \%$ & $2.23 \%$ \\
\hline
\end{tabular}




\begin{tabular}{ccccccc}
\hline Ward Effects & Yes & Yes & Yes & Yes & Yes & Yes \\
Heating Type & Yes & Yes & Yes & Yes & Yes & Yes \\
Dwelling Chars & Yes & Yes & Yes & Yes & Yes & Yes \\
Household Chars & Yes & Yes & Yes & Yes & Yes & Yes \\
R-squared & 0.3198 & 0.3065 & 0.2991 & 0.2973 & 0.2985 & 0.2974 \\
N.of cases & 11030 & 14531 & 18056 & 23082 & 28994 & 34584 \\
\hline
\end{tabular}

Dwelling characteristics omitted from the table include home type, house age, number of rooms. Household characteristics omitted from the table include number of adults, dependent children, elderly, and workers in the household, how long the household has lived in this home (duration), duration squared, a college education dummy, renter dummies, and a student house dummy. Full regression results are available upon request from the authors. 
Table 13. Robustness checks. All regressions are based on the specifications of table 11, unless otherwise indicated.

\begin{tabular}{|c|c|c|c|c|c|c|c|c|c|}
\hline \multirow{2}{*}{ A. } & \multicolumn{3}{|c|}{$\begin{array}{l}\text { Drop bottom } 10 \% \text { of income } \\
\text { distribution in the sample }\end{array}$} & \multicolumn{3}{|c|}{ drop if income is missing } & \multicolumn{3}{|c|}{ drop if income is topcoded } \\
\hline & $\begin{array}{l}2000- \\
2005\end{array}$ & $\begin{array}{l}1999- \\
2996\end{array}$ & $\begin{array}{l}\text { all } \\
\text { years }\end{array}$ & $\begin{array}{l}2000- \\
2005\end{array}$ & $\begin{array}{l}1999- \\
2996\end{array}$ & $\begin{array}{l}\text { all } \\
\text { years }\end{array}$ & $\begin{array}{l}2000- \\
2005\end{array}$ & $\begin{array}{l}1999- \\
2996\end{array}$ & \begin{tabular}{|l|l|} 
all \\
years
\end{tabular} \\
\hline$\Delta$ & -0.1250 & -0.1512 & -0.1959 & -0.1042 & -0.1417 & -0.1872 & -0.1151 & -0.1537 & -0.1930 \\
\hline s.e. $(\Delta)$ & 0.0271 & 0.0239 & 0.0178 & 0.028 & 0.0244 & 0.0178 & 0.0267 & 0.0215 & 0.0168 \\
\hline $\begin{array}{l}\text { effect on } \\
\text { consumption }\end{array}$ & $75 \%$ & $-14.04 \%$ & $17.79 \%$ & $-9.90 \%$ & $-13.21 \%$ & $17.07 \%$ & $-10.87 \%$ & $-14.25 \%$ & $17.55 \%$ \\
\hline $\begin{array}{l}\text { s.e.(effect on } \\
\text { consumption) }\end{array}$ & $2.04 \%$ & $.06 \%$ & $1.45 \%$ & $2.52 \%$ & $2.11 \%$ & $1.28 \%$ & $2.38 \%$ & $1.84 \%$ & $1.38 \%$ \\
\hline $\mathrm{N}$ & 12823 & 16871 & 41188 & 11470 & 15306 & 38905 & 12313 & 16294 & 40055 \\
\hline
\end{tabular}

\begin{tabular}{|c|c|c|c|c|c|c|c|c|c|}
\hline \multirow{2}{*}{ B. } & \multicolumn{3}{|c|}{ exclude price and weather } & \multicolumn{3}{|c|}{$\begin{array}{l}\text { exclude sociodemographics } \\
\text { and income }\end{array}$} & \multicolumn{3}{|c|}{$\begin{array}{l}\text { omit selection correction } \\
\text { terms }\end{array}$} \\
\hline & $\begin{array}{l}2000- \\
2005\end{array}$ & $\begin{array}{l}1999- \\
2996\end{array}$ & $\begin{array}{l}\text { all } \\
\text { years }\end{array}$ & $\begin{array}{l}2000- \\
2005\end{array}$ & $\begin{array}{l}1999- \\
2996\end{array}$ & $\begin{array}{l}\text { all } \\
\text { years }\end{array}$ & $\begin{array}{l}2000- \\
2005\end{array}$ & $\begin{array}{l}1999- \\
2996\end{array}$ & $\begin{array}{l}\text { all } \\
\text { years }\end{array}$ \\
\hline$\Delta$ & -0.0947 & -0.1363 & -0.1966 & -0.1341 & -0.1694 & -0.2189 & -0.0952 & -0.1314 & -0.1687 \\
\hline s.e. $(\Delta)$ & 0.0265 & 021 & 0.0165 & 0.0244 & 0193 & 78 & 54 & 214 & 0171 \\
\hline $\begin{array}{l}\text { effect on } \\
\text { consumptior }\end{array}$ & $-9.04 \%$ & $4 \%$ & $17.85 \%$ & & -15 & 1 & $9 \%$ & -12 & $15.53 \%$ \\
\hline $\begin{array}{l}\text { s.e.(effect c } \\
\text { consumptic }\end{array}$ & $2.41 \%$ & $1.84 \%$ & $35 \%$ & $2.13 \%$ & $1.64 \%$ & $1.43 \%$ & $2.31 \%$ & $1.88 \%$ & $1.44 \%$ \\
\hline $\mathrm{N}$ & 13591 & 17918 & 44917 & 13661 & 17990 & 45121 & 15391 & 17918 & 44917 \\
\hline
\end{tabular}

\begin{tabular}{|l|c|c|r|}
\hline C. & \multicolumn{3}{|c|}{ include year dummies } \\
\hline sample period & $\begin{array}{l}2000- \\
2005\end{array}$ & $\begin{array}{l}1999- \\
2996\end{array}$ & $\begin{array}{l}\text { all } \\
\text { years }\end{array}$ \\
\hline$\Delta$ & -0.1048 & -0.1550 & -0.1808 \\
\hline s.e.( $\Delta)$ & 0.0278 & 0.0188 & 0.0161 \\
\hline $\begin{array}{l}\text { effect on } \\
\text { consumption }\end{array}$ & $-9.95 \%$ & $-14.35 \%$ & $16.54 \%$ \\
\hline $\begin{array}{l}\text { s.e.(effect on } \\
\text { consumption) }\end{array}$ & $2.50 \%$ & $1.61 \%$ & $1.35 \%$ \\
\hline $\mathrm{N}$ & 13591 & 17918 & 44917 \\
\hline
\end{tabular}

